Article

\title{
Sustainable Residential Building Considerations for Rural Areas: A Case Study
}

\author{
Lawrence Fulton*(-), Bradley Beauvais, Matthew Brooks, Scott Kruse ${ }^{\circledR}$ and Kimberly Lee \\ Health Administration, Texas State University, San Marcos, TX 78666, USA; bmb230@txstate.edu (B.B.); \\ mbrooks@txstate.edu (M.B.); scottkruse@txstate.edu (S.K.); Kim.lee@txstate.edu (K.L.) \\ * Correspondence: lf25@txstate.edu
}

Received: 4 April 2020; Accepted: 12 May 2020; Published: 15 May 2020

check for updates

\begin{abstract}
Intelligent use of rural residential land and sustainable construction is inexorably linked to cost; however, options exist that are eco-friendly and have a positive return on investment. In 2011, a research residence was built to evaluate various land-use and sustainable components. This Texas house has subsequently been used for both residential and research purposes. The purpose of this case study was to evaluate break-even construction considerations, to assess environmental impacts, and to evaluate qualitatively efficacy of sustainable options incorporated in the research residence. Some of the specific components discussed are home site placement (directional positioning); materiel acquisition (transportation); wood product minimization; rainwater harvesting; wastewater management; grid-tied solar array power; electric car charging via a solar array; geothermal heating and cooling; insulation selection; windows, fixtures, and appliance selection; and on-demand electric water heaters for guest areas. This study seeks to identify the impact of proper land use and sustainable techniques on the environment and return-on-investment in rural areas. Break-even and 15-year Net Present Value (NPV) analysis at 3\% and 5\% cost of capital were used to evaluate traditional construction, partially sustainable construction, and fully sustainable construction options for the case study house, which was built sustainably. The additional cost of sustainable construction is estimated at $\$ 54,329$. At $3 \%$, the analysis suggests a 15 -year NPV of $\$ 334,355$ (traditional) versus $\$ 250,339$ million (sustainable) for a difference of $\$ 84 \mathrm{~K}$. At $5 \%$ cost of capital, that difference falls to $\$ 63 \mathrm{~K}$. The total estimated annual difference in carbon emissions is 4.326 million $\mathrm{g} / \mathrm{CO}_{2} \mathrm{e}$ for this research residence. The results indicate that good choices for quick return-on-investment in rural construction would be the use of engineered lumber, Icynene foam, and Energy Star windows and doors. Medium-term options include photovoltaic systems (PVS) capable of powering the home and an electric car. Sustainable construction options should positively affect the environment and the pocketbook. Regulations and code should require adoption of short-range, break-even sustainable solutions in residential construction.
\end{abstract}

Keywords: rural residential construction; rainwater harvesting; solar; spray foam; finger-jointed studs

\section{Introduction}

Sustainable rural land use requires environmentally sound residential construction [1]. Residential (and commercial) construction options affect the water supply [2], water demand [3,4], electricity demand [5-8], the use of land lumber and other materials [9,10], as well as the entire ecosystem [11]. Improper use of land can accelerate global warming [12,13], have impacts on human health (particularly in regards to disease) [14], lead to eutrophication/acidification of water [15,16], and cause smog formation in urban areas $[17,18]$. Perhaps unsurprisingly, land-use impacts are most affected by the use of wood products [19]. Sustainable construction begins with planning. 


\subsection{Planning and Transportation Considerations}

When planning for sustainable residential construction, site placement is important to consider predominant winds and facing for solar capture [20,21]. Pre-planning of construction should include a significant sustainability analysis, and techniques such as simulation are helpful to this process [22,23]. Also important is minimizing the transportation costs (a construction waste), which include consciously purchasing materials that are located closer to the construction site [24]. Waste produced during the construction should be minimized and recycled where possible, and a construction waste management plan should include subcontractor incentives [25]. Since lumber waste is the largest contributor to detrimental land-use effects [19], the use of engineered lumber (as well as other resources) are possible solutions [26,27]. The planning for waste management must begin in the design cycle [28].

\subsection{Global Warming Potential}

Another consideration in pre-planning of residential construction is reducing the impacts on Global Warming Potential (GWP) balanced by a tight residential envelope to reduce requirements for heating and cooling energy. As an example, Icynene foam insulation currently has the lowest possible GWP of 1.0 [29] and provides a tight house envelope, which is a winning combination. Fenestration considerations (e.g., the installation of Energy Star windows and doors) are important to maintain the building envelope according to human and environmental considerations [30]. A residence's thermal mass is vital to achieve reductions in energy demand [31].

\subsection{Electricity}

Energy demands of residences must be considered prior to construction as well. Photovoltaic systems (PVS), wind energy, and nuclear-power grid energy reduce the carbon footprint of the residence when compared to traditional fossil fuel and sequestration plants. The difference is estimated to be from 78 to $110 \mathrm{gCO}_{2} \mathrm{eq} \mathrm{kWh}-1$ to 3.5 to $12 \mathrm{gCO}_{2} \mathrm{eq} \mathrm{kWh}-1$ [32]. The use of solar water heaters or tankless electric water heaters powered by a PVS are two of many options that may reduce both cost and kWh demand [33]. Further, electric cars charged by PVS that are sized properly for residential and transportation demands may reduce environmental impacts, as will the proper choice of Heating Ventilation and Air Conditioning (HVAC) [9,34].

Some new residential construction has attempted to reduce the demand for grid electricity and slow global warming by Net-Zero (or even Net-Positive) construction, which involves the design of facilities that either consume no net energy (demand less than supply) or that produce more energy than consumption [35,36]. Net-Zero construction may even power user transportation, further reducing the impact of the built environment $[37,38]$. Net-Zero homes coupled with proper water management and residential construction techniques may mitigate many of the environmental effects associated with residential construction [9].

\subsection{Water and Wastewater}

Water life-cycle considerations are vital when constructing houses in rural areas, particularly in rule-of-capture states that allow for exploitation of common-use groundwater [39]. The source of water should be responsibly considered (e.g., well water, rainwater harvesting, or municipal water connections, assuming they exist). Well contamination in rural communities is a significant consideration [40-42], and municipal water connections may be unavailable. Rainwater harvesting is then an option, which reduces the overall supply requirements for each gallon demanded when compared to groundwater and which has other beneficial properties including softness [43-45]. Environmentally responsible use of any water source must consider the use of low-flow fixtures. Use of these fixtures resulted in a 22\% reduction in average annual household usage from 1999 to 2016 [46]. Further, xeriscaping reduces water requirements, can contribute to the success of construction projects, and should be part of best practices in arid and semiarid regions particularly [47]. Part of the water 
life cycle requires disposal of black water. In rural areas, no municipal sewage system may exist, so the options are aerobic or anaerobic sewer systems. While aerobic systems break down waste more quickly than anaerobic systems, they are more expensive from both acquisition and maintenance perspectives [48].

\subsection{Purpose and Research Questions}

This case study analyzes best-practice construction design for both the environment and the consumer based on a rural residence designed in 2011 for research purposes. This residence was the highest-rated house ever certified by the National Association of Home Builders (NAHB) at the time it was built [37]. NAHB sets standards for rating construction based on energy efficiency, water conservation, resource conservation, indoor environmental quality, site design, and homeowner education [49]. The actual standards are available here: [50]. Both construction successes and failures are analyzed with commentary from both the environmental and consumer perspective.

The primary research question addresses which sustainable construction options in this case study would also achieve breakeven (and when) if built today, as well as how sustainable these interventions are in terms of environmental impact. A secondary component of the study investigates the Net Present Value (NPV) of two different construction options that were available for building the research residence: traditional and sustainable. The time horizon investigated was 15 years. Comparing these three building decisions helps inform the value of green construction. Further, qualitative assessments of the sustainable interventions are provided.

\subsection{Significance}

The study's significance is that it investigates which sustainable options may result in a reasonable break-even period and whether planning of proper land use and application of sustainable construction may produce a return-on-investment while minimizing environmental effects. While this case study is not generalizable, the equations provided to compare both cost and environmental considerations may be applied to any other case, making the study useful. Further, the experiential component of the study spans nearly a decade of lived experience. No literature exists from a researcher in this area who has lived the results of the sustainable experimentation, which makes this study unique.

The study is also significant to increasing use of renewable sources in Texas. The use of solar or wind power solutions becomes increasingly relevant to rural Texans [51], and the state had over 28,871 MW of installed wind capacity at the end of 2019 [52]. Figure 1 shows that, in many areas of rural Texas (identified in Figure 2), the average wind speed would support wind turbine construction. Figure 3 illustrates the solar production potential by state

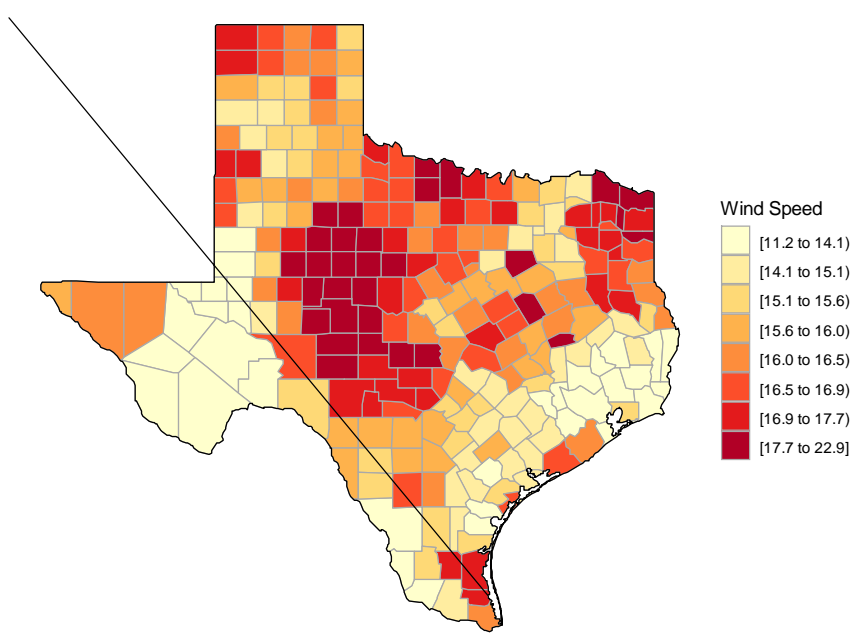

Figure 1. Choropleth map of wind speed by county in Texas. 


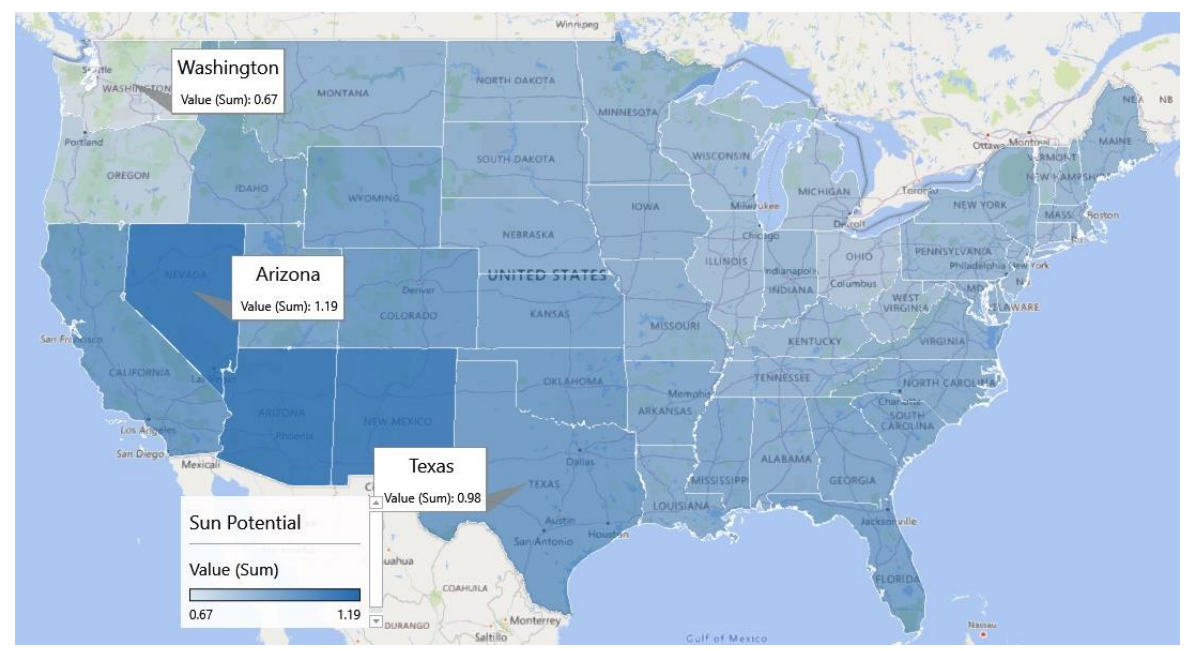

Figure 2. Choropleth of state solar production potential.

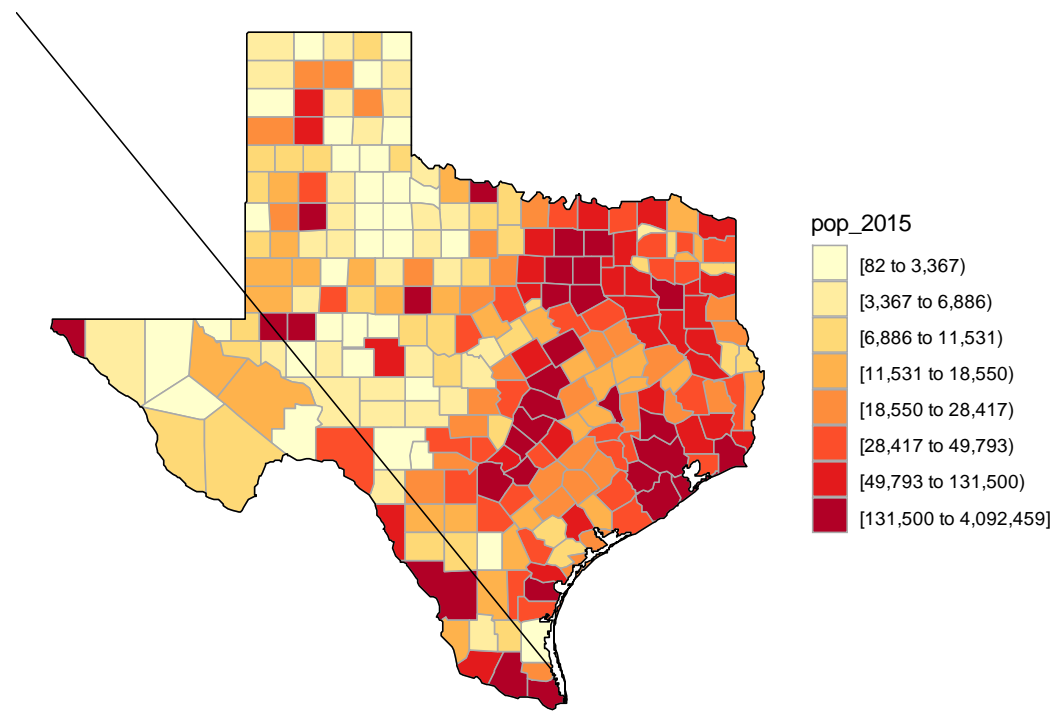

Figure 3. Distribution of Population Intensity in Texas.

\subsection{Generalizability}

While this is a case study, the majority of Texas is actually rural (Census Bureau data, [53]), so the techniques discussed are widely applicable within the state (see Figure 3, mapped in R Statistical Software [54] using the software library "choroplethr" [55]). Further, there is evidence that both new housing as well as renovations and modifications are needed in the rural areas of Texas [56], so this case study is made more important in that it provides some best-practice considerations. The rural areas in Texas often face enormous electrical transmission and distribution rates, sometimes twice the state average [57].

The study proceeds as follows. First, a discussion of Net Present Value (NPV) and break-even analysis is explicated in Section 2. Following this section, Section 3 evaluates the elements of construction included in the sustainable house, which is the subject of the study. After a discussion of these elements, analysis of various constructions based on the study residence are evaluated in terms of both break-even timing and NPV. Finally, ideas and insights are provided in the discussion and conclusion, Sections 4 and 5 , respectively. 


\section{Materials and Methods}

In this case study, we evaluated deterministically the environmental impacts, life-cycle costs, and efficacy of multiple sustainable building innovations for rural residences versus more traditional construction. The rural research residence informing this study is an approximately 4800 square foot home (446 square meters) and located in a semiarid environment in Texas. The options used in this construction are compared directly against more traditional options for both cost and environmental effects.

The study evaluates home site placement; materials transportation; reclaimed wood framing; spray-foam insulation; window, fixture, and appliance selection; material recycling; rainwater harvesting design and engineering; aerobic septic system; xeriscaping; grid-tied solar arrays; electric car charging and use; on-demand water heaters; geothermal heating and cooling; and electrical back-up system options. The home has supported between 2 and 3 full-time, middle-aged residents (one adult worker) with seasonal demand of up to 20 individuals during holidays over the last 9 years. The residence was occupied shortly after its construction and has been in constant use.

\subsection{Break-Even Analysis}

Specific methods used include deterministic break-even analysis for each element evaluated (if one exists) based on acquisition costs of the sustainable option versus one or more other options. Break-even analysis evaluates monetary outflows of residential construction options (as well as any returns) and evaluates at what point (if ever) total costs of both options intersect [58]. The break-even point is determined using Equation (1). The break-even point is then when total costs of one option equal total costs of another option. In this equation, $F C$ stands for fixed costs, $V C$ represents variable costs (e.g., maintenance and operations), and the index set represents the option number and time index. There are some semi-variable costs (e.g., step functions for item replacements) involved in the construction analysis, and these are included in the variable costs.

$$
F C_{1 t}+V C_{1 t}-F C_{2 t}-V C_{2 t}=0
$$

\subsection{Net Present Value}

As part of the analysis, this case study evaluated three different construction possibilities for the original research residence and their associated profitability using net present value (NPV). Two of the three construction options are at opposite ends of the spectrum (traditional versus sustainable), while the third uses many of the sustainable elements with a positive NPV. NPV is calculated according to Equation (2), where $i$ is the index for the option selected, $R_{t}$ is the net cash inflow and outflows at time $t, A$ is the accumulation rate $(1+$ return rate), and $n$ is the number of time periods evaluated [59]. The time period used for NPV analysis is 15 years.

$$
N P V_{j}=\sum_{t=1}^{n} \frac{R_{t}}{A^{t}}
$$

\subsection{Construction Components Evaluated/Data Sources}

The case study involves a single structure built in one specific way; however, it also evaluates breakeven and NPV had it been built in alternative ways to provide useful comparisons for the reader. Table 1 provides the category, the items evaluated, the data sources, and the cradle-to-grave cost estimates with comments for those items. Some elements discussed in the case study are not included in the breakeven and NPV analysis, however. These elements (such as site placement) may have an effect in either direction, but the size and directionality are unknown. 
Table 1. Construction categories and components evaluated (inflation at 3\% per year).

\begin{tabular}{|c|c|c|c|c|c|}
\hline Category & Traditional Option & 15-Year Costs & Sustainable Option & 15-Year Costs & Environmental Difference \\
\hline Framing & Lumber & $\$ 52,800$ & Engineered Lumber & $\$ 53,184$ & 24.5-90 Trees \\
\hline Insulation & Fiberglass & $\$ 14,4200$ & Icynene Foam & $\$ 12,460$ & Reduced $\mathrm{CO}_{2}$ or PVS \\
\hline Fenestration & Standard & $\$ 14,457$ & Energy Star & $\$ 16,625$ & Reduced $\mathrm{CO}_{2}$ or PVS \\
\hline Water & Well & $\$ 33,563$ & Rainwater Harvesting & $\$ 32,111$ & Reduced $\mathrm{H} 20$ requirement \\
\hline Wastewater & Anaerobic & $\$ 7531$ & Aerobic & $\$ 14,128$ & Fewer pollutants \\
\hline Water Heaters & Electric H20, Tank & $\$ 22,915$ & Tankless & $\$ 3000$ & Reduced $\mathrm{CO}_{2}$ or PVS \\
\hline Electricity & Grid & $\$ 62,834$ & Solar & $\$ 54,480$ & Reduced $\mathrm{CO}_{2}$ or PVS \\
\hline Vehicle & $\operatorname{ICEV}(\times 2)$ & $\$ 107,777$ & $\mathrm{BEV}(\times 2)$ & $\$ 92,288$ & Reduced GHG \\
\hline \multirow[t]{2}{*}{ HVAC } & Heat Pump & $\$ 112,383$ & Geothermal & $\$ 30,644$ & Reduced $\mathrm{CO}_{2}$ or PVS \\
\hline & Total, Traditional & $\$ 428,680$ & Total Sustainable & $\$ 308.920$ & \\
\hline
\end{tabular}

Abbreviations: Heating Ventilation Air Conditioning (HVAC), Internal Combustion Engine Vehicle (ICEV), Battery Electric Vehicle (BEV), Greenhouse Gases (GHG), Photovoltaic System (PVS).

In the subsequent sections, the study explicates the acquisition and operations and maintenance $(\mathrm{O} \& \mathrm{M})$ costs for each of these categories. Data for each of the areas evaluated from breakeven were acquired from peer-reviewed literature where possible and from construction firms where there were no data (e.g., engineered lumber versus traditional studs). Data ranges were sought, and the midpoints of these ranges were used for deterministic calculations.

\subsection{Environmental and Qualitative Analysis}

When relevant, an analysis of the environmental advantages of sustainable construction versus other options is provided. Relevant research from the literature is extracted to estimate carbon emissions, water quality, etc., similar to Fulton et al. (2020) [9]. Part of the sustainable construction assessment was a qualitative assessment involving elements of the triple bottom line (TBL) [60]. The experience of the research team and home resident augment the data-driven analysis.

\subsection{Data and Software}

Data for the deterministic breakeven and return on investment (ROI) portions of this case study were garnered from previous research as well as data sources appropriate to the residence itself. All analyses were conducted in Microsoft Office Excel 2016 and R Statistical Software [54].

\section{Results}

\subsection{Initial Considerations}

\subsubsection{Construction Planning, Permitting, and Analyses}

The land was two years prior to construction, as the design process required significant planning, permitting, and modeling. Aside from the typical surveying, permits for operating an on-site sewer facility and (later) driveway placement were required [61]. At the time, the maximum grid-tied PVS array permitted by the utility company was $10 \mathrm{~kW}$, so a waiver was required based on analysis of user consumption. Utility pole transformer size was analyzed and found acceptable without resizing. Further, the utility company regulated the grid-tied interconnection of the backup propane generation system [62]. As an example of analysis conducted prior to building, the sizing of the rainwater harvesting system was estimated through simulation [43]. Construction waste management and recycling required significant preplanning, and the well placement for the geothermal HVAC had to be mapped and approved. The processes described here required approximately six months of lead time, which is a consideration should quicker construction be required. Construction planning, permitting, and analyses are not part of the break-even or NPV analyses. 


\subsubsection{Site Placement}

The rural residence in the study was designed from the ground up to be sustainable, and the design considerations included geographical placement. The home site was selected to be north-facing to maximize solar capture (west-, south-, and east-facing panels) and to leverage predominant local winds (south to north) [20]. Further, the site selected minimized tree removal, reducing cost and effect on the environment. Qualitatively, the placement was a success in this construction, as the solar capture is as expected (discussed later), and the cost as well as the environmental impact of excess tree removal was avoided. Figure 4 is the Google Maps satellite image of the house with various sustainable callouts that are referenced later [63]. Site placement is not per se evaluated in the break-even and NPV analyses.

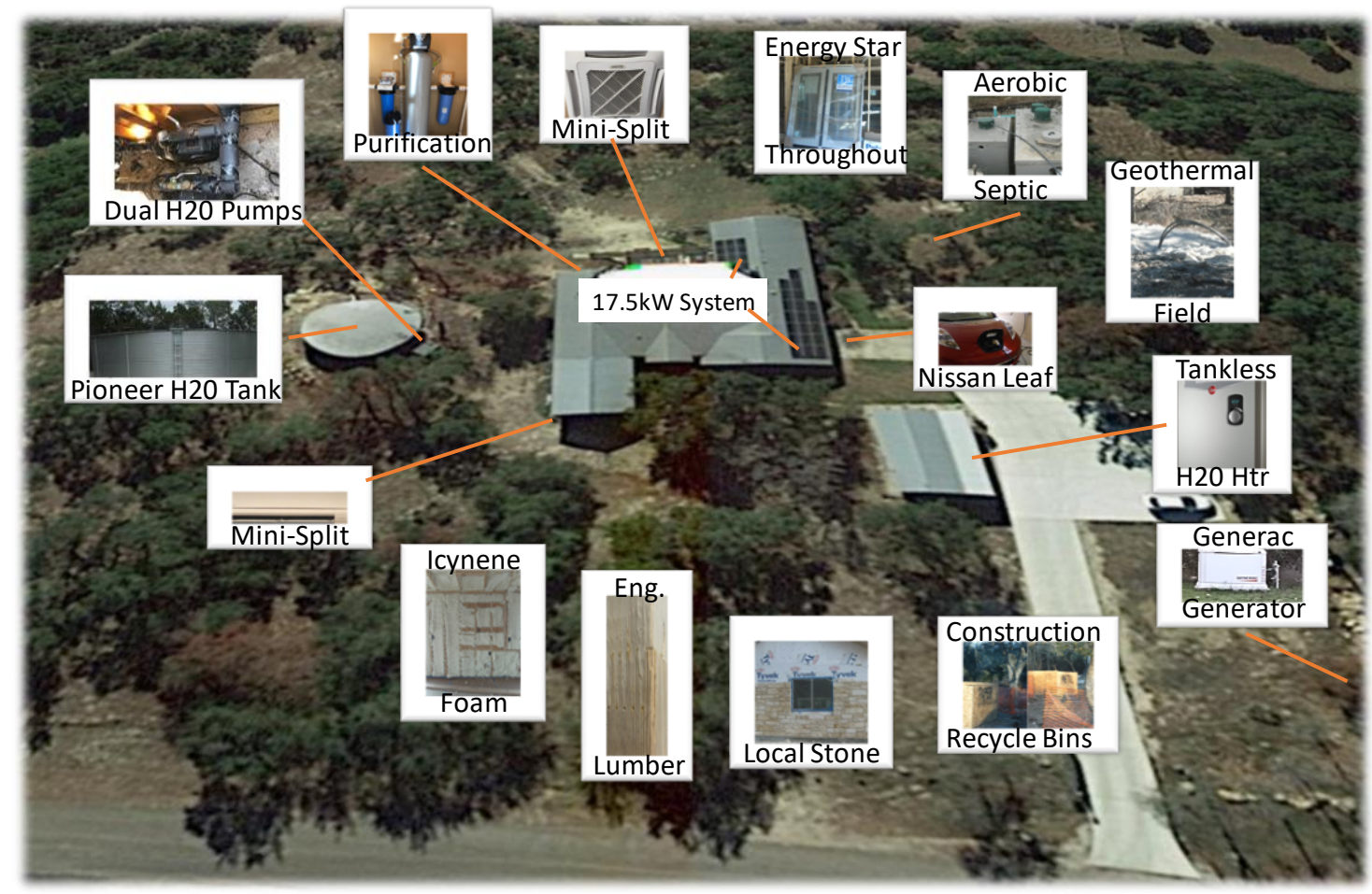

Figure 4. The residence as constructed.

\subsubsection{Material Location/Transportation}

One of the major sustainability considerations in residential construction is the transportation of materials [64]. As part of the rural residence design, only local materials (those within 50 miles) were selected. For example, local limestone was selected for the exterior. Reducing transportation requirements reduces emissions. One study found a $215 \%$ decrease in the amount of energy used in building and a $453 \%$ decrease in the impact of transportation when local building supplies were used [65]. The reduction in environmental impact is measurable and significant. Estimating the savings in construction for use of these materials is difficult and omitted from this case study.

\subsubsection{Waste Collection and Recycling}

During construction, bins for waste were used to recycle materials as appropriate (Figure 4). Metals, plastic, and glass were recycled, congruent with previous research [64]. Doing so allowed for reclaimed wood to be fabricated into engineered lumber and for used paper and metal to be used in other capacities. While this has little to no bearing on cost (perhaps $2.5 \%$ back to the builder [66]), it does have an effect on the environment. In terms of Global Warming Potential, recycling has the 
greatest impact versus incineration or landfill options [67]. This is the last element that is not included in the break-even and NPV analyses.

\subsection{Engineered Lumber/Finger-Jointed Studs}

Reclaimed wood (specifically finger-jointed studs) were used in the residential construction (see Figure 4). These studs are also straighter and result in less wood wasted. They neither split nor twist like traditional studs [68]. Further, they have a strong vertical load capability, with evidence that many species (including pine) have better structural properties when finger-jointed, although that evidence is mixed [69].

\subsubsection{Environmental Considerations}

A 20" diameter tree with 42 feet length of usable wood produces about 260 board feet. The Idaho Forest Products Commission estimated that a typical 2000 square foot house would use 102 trees of that size [70]. Assuming linearity, the rural residence, a 4800 square foot home (446 square meters, would have been estimated to require approximately 245 trees. Assuming an offset of even $25 \%$ of the wood requirements results in a reduction of about 61 trees. See Table 2. For this deterministic study, the estimate of trees saved would be between 24.5 and 98 given the size of the house.

Table 2. Estimate of trees saved by using engineered lumber (finger-jointed studs) in this case study.

\begin{tabular}{cc}
\hline$\%$ Offset of Traditional Lumber & Trees Saved \\
\hline $10 \%$ & 24.5 \\
$15 \%$ & 36.8 \\
$20 \%$ & 49.0 \\
$25 \%$ & 61.3 \\
$30 \%$ & 73.5 \\
$35 \%$ & 85.8 \\
$40 \%$ & 98.0 \\
\hline
\end{tabular}

\subsubsection{Acquisition and 15-Year Operations and Maintenance (O\&M) Costs}

The cost of finger-jointed studs may be more expensive than regular studs. For example, the retail cost of a $2 \times 4 \times 1045 / 8^{\prime \prime}(0.6 \times 1.2 \times 2.7$ meters $)$ regular pine stud versus the same size finger-jointed stud is listed at $\$ 3.62$ [71] versus $\$ 5.59$ [72], respectively. This is a $54.4 \%$ cost increase for materials (much less than estimated by [69] for pine), which might be offset by lower labor costs due to engineered lumber's straightness.

The cost differential is not atypical, as many engineered lumber products have upcharges between 1.5 and 2 times the cost of traditional lumber $[69,72]$. One site estimates the total cost of traditional framing between $\$ 4$ and $\$ 10$ per square foot for labor and $\$ 3$ and $\$ 6$ per square foot for materials [73]. With a $30 \%$ reduction in labor costs for engineered lumber, low material costs for standard lumber, and $54.4 \%$ higher costs in engineered lumber, there are several ways in which finger-jointed studs might actually save money. Table 3 illustrates those combinations (2020 dollars).

Using the average estimate of $\$ 7$ for labor and $\$ 4$ for materials (traditional construction) and 30\% reductions in labor $(\$ 4.90)$ with $54.4 \%$ increases in materials $(\$ 6.18$, nontraditional construction) results in comparative estimates of $\$ 52,800$ (traditional stud construction) and $\$ 53,184$ (engineered lumber), underlined in Table 3. The total difference in cost is estimated to be nominal, but the environmental impact is not, as it saves old-growth trees [26]. O\&M costs are considered nominal for the 15-year NPV analysis. 
Table 3. Regular lumber versus finger-jointed studs cost per square foot of construction and total.

\begin{tabular}{ccccccc}
\hline & \multicolumn{2}{c}{ Regular Lumber, $\$ / \mathbf{f t}^{2}$} & \multicolumn{3}{c}{ Engineered Lumber, $\mathbf{\$} \mathbf{f t}^{\mathbf{2}}$} & \multicolumn{1}{c}{ Savings } \\
\hline Materials & Labor & A. Total $\$$ for House & Materials & Labor & B. Total $\$$ for House & A-B \\
\hline$\$ 3.00$ & $\$ 10.00$ & $\$ 62,400.00$ & $\$ 4.62$ & $\$ 7.00$ & $\$ 55,776.00$ & $\$ 6624.00$ \\
$\$ 3.00$ & $\$ 9.00$ & $\$ 57,600.00$ & $\$ 4.62$ & $\$ 6.30$ & $\$ 52,416.00$ & $\$ 5184.00$ \\
$\$ 4.00$ & $\$ 10.00$ & $\$ 67,200.00$ & $\$ 6.16$ & $\$ 7.00$ & $\$ 63,168.00$ & $\$ 4032.00$ \\
$\$ 3.00$ & $\$ 8.00$ & $\$ 52,800.00$ & $\$ 4.62$ & $\$ 5.60$ & $\$ 49,056.00$ & $\$ 3744.00$ \\
$\$ 4.00$ & $\$ 9.00$ & $\$ 62,400.00$ & $\$ 6.16$ & $\$ 6.30$ & $\$ 59,808.00$ & $\$ 2592.00$ \\
$\$ 3.00$ & $\$ 7.00$ & $\$ 48,000.00$ & $\$ 4.62$ & $\$ 4.90$ & $\$ 45,696.00$ & $\$ 2304.00$ \\
$\$ 5.00$ & $\$ 10.00$ & $\$ 72,000.00$ & $\$ 7.70$ & $\$ 7.00$ & $\$ 70,560.00$ & $\$ 1440.00$ \\
$\$ 4.00$ & $\$ 8.00$ & $\$ 57,600.00$ & $\$ 6.16$ & $\$ 5.60$ & $\$ 56,448.00$ & $\$ 1152.00$ \\
$\$ 3.00$ & $\$ 6.00$ & $\$ 43,200.00$ & $\$ 4.62$ & $\$ 4.20$ & $\$ 42,336.00$ & $\$ 864.00$ \\
$\$ 5.00$ & $\$ 9.00$ & $\$ 67,200.00$ & $\$ 7.70$ & $\$ 6.30$ & $\$ 67,200.00$ & $\$ 0.00$ \\
\hline
\end{tabular}

\subsection{Residential Envelope}

Residential spray-foam insulation (Figure 4) provides a thermal barrier with exceedingly low conductivity $(0.021 \mathrm{~W} / \mathrm{mK}$ in one study [74]). Icynene spray foam has reasonable hygrothermal properties and is resistant to moisture migration; however, mechanical extraction and humidity controls may need to be installed (as in the case study) because of the tight environmental seal of the house and the requirement to exchange air. The practical relevance of the tight seal around the rural residence is that, during the heat of the summer in this semiarid region (in excess of $100{ }^{\circ} \mathrm{F}, 38^{\circ} \mathrm{C}$ ), the observed temperature in the attic spaces does not exceed $80^{\circ} \mathrm{F} / 26.7^{\circ} \mathrm{C}$ with the house thermometer set to $76^{\circ} \mathrm{F} / 24.4^{\circ} \mathrm{C}$.

\subsubsection{Environmental Considerations}

From an environmental perspective, water-blown Icynene spray-foam insulation has a reduced carbon footprint from better HVAC usage [9]. Still, other forms of insulation have better characteristics for insulation, although not necessarily cost profile [75]. In retrospect, alternative materials would probably be used for the case study residence if built now.

\subsubsection{Acquisition Costs and 15-Year O\&M}

The 2020 cost for open-cell spray-foam insulation is about $\$ 0.35$ to $\$ 0.55$ per board foot [76], which is lower than the cost estimated by Kalhor and Ememinejad [77] ( $\$ 0.80$ to $\$ 1.30$ ) but nearly identical to the cost found on the manufacturer's website [78] (\$0.40 to $\$ 0.60$ ). To account for regional variation, the information from [76] is used for Icynene foam cost estimates. A 3.5" depth of spray converts to $\$ 1.23$ to $\$ 1.93$ per square foot or $\$ 13.24$ to $\$ 20.77$ per square meter. Fiberglass batt insulation runs $\$ 0.64$ to $\$ 1.19$ per square foot or $\$ 6.89$ to $\$ 12.81$ per square meter [76]. Assuming average costs of $\$ 1.58$ per square foot (spray-foam) and $\$ 0.915$ (fiberglass) with 8000 square feet of attic and walls to be insulated (estimated from case study house) results in cost estimates of $\$ 12,640$ and $\$ 7320$, respectively [79], but the second estimate is not complete.

Spray foam works as an air barrier, vapor barrier, water-resistant barrier, and insulation. There is no need for attic vents, test ductwork, or air-seal attics. When evaluated in this manner, it is actually 10-15\% less expensive than traditional construction [79]. Adding $12.5 \%$ (the average between 10\%-and $15 \%$ ) to the $\$ 12,640$ estimate for spray-foam construction results in an estimate of $\$ 14,420$ for insulation, vapor barrier, vents, test duct work, etc. For the break-even analysis, then, the final values used were $\$ 12,460$ for the installation of Icynene and $\$ 14,420$ for use of fiberglass.

\subsubsection{Qualitative Assessment}

Spray foam makes the attic space usable in hot weather. While this may be a minor point, it is an important consideration for homeowners considering building options. 


\subsection{Low Solar Heat Gain Coefficient (SHGC) and U-Factor Windows (Energy Star)}

Solar Heat Gain Coefficient (SHGC) is defined as the fraction of incident solar radiation admitted through a window. In warm climates, windows should have solar heat gain coefficients (SHGC) less than 0.25 [80]. Further, the U factor, a factor that expresses the insulative value of windows, should be 0.4 or lower. Low-emissivity windows and doors with SHGC of 0.23 and U-Factor of 0.3 were used throughout the case study house.

\subsubsection{Environmental Considerations}

The selection of Energy Star windows and doors resulted in a smaller sizing for the PVS system, as the demand for heating and cooling is $17 \%$ to $31 \%$ less [81]. There is no achievable carbon output reduction by use of these windows on a house that is already $100 \%$ reliant on PVS (except for gray energy). (For a traditional grid-powered residence, that savings might be between 246 and 6205 lbs. of $\mathrm{CO}_{2}$ [81].)

\subsubsection{Acquisition and 15-Year O\&M Costs}

Low-emissivity windows are $10 \%$ to $15 \%$ more expensive than standard windows [82], although one study indicated that the cost was about $\$ 50$ more per window [83]. The typical cost range in 2020 dollars is $\$ 385$ to $\$ 785$, with an average of $\$ 585$ [84]. The Department of Energy estimates savings of $\$ 125$ to $\$ 465$ dollars a year from replacing windows with new windows that have higher Energy Star ratings [81], which is lower than estimated in [83]. Assuming average cost for Energy Star windows (\$585), 15\% less expensive traditional windows (\$508.70), and a total of 25 windows (based on the case study house construction) results in acquisition costs of $\$ 14,625$ (Energy Star) versus $\$ 12,717.50$ (non-Energy Star). Exterior door costs vary greatly depending on type and nature. For the case study facility, one Energy Star double door and single door were installed at a cost of $\$ 2000$. Assuming a $15 \%$ premium (as in the case of the windows), standard doors would be estimated at $\$ 1739.13$. The total cost for Energy Star versus standard windows and doors is then $\$ 16,625$ and $\$ 14,457$, respectively (not including any applicable tax credits if available). No O\&M costs are estimated during the 15-year window used for NPV analysis.

\subsection{Rainwater Harvesting}

The decision to install a rainwater harvesting system (RWH) versus a well or city water is one that is entirely dependent on the environment, the availability of municipal water, the homeowner's wishes, and regulations. In this case study, no city water sources were available. After a cost analysis, it was estimated that the cost for a well and the cost for a rainwater harvesting system (at the time of build) would be nearly identical largely due to well-depth requirements (1200').

Figure 5 depicts the RWH as currently installed in the rural residence. The system works as follows. Rainwater falls on the roof and is captured by gutters. The guttered water flows to the cistern where 100 gallons or so is flushed out through a pipe with a ball float to eject the debris on the roof. Once the ball float seals the flushing tube, the water continues into French drain and basket filters and then into a cistern. Parallel on-demand pumps push water towards the house where it is processed through a sediment filter, charcoal regeneration system, and ultraviolet light, which is an effective method for inactivating pathogens through irradiation [85].

Quality considerations for water are significant. Using rainfall for potable house needs requires proper roof selection (ceramic or metal as examples), flushing (first flush), gross filtering (e.g., French drain and basket filters), storage (food-grade butyl rubber), pumping, cleansing (e.g., sediment filter and charcoal regeneration), purifying (ultraviolet purification as one example), and disposal of gray water (aerobic septic system). Baseline quality construction requirements are found in [86]. 


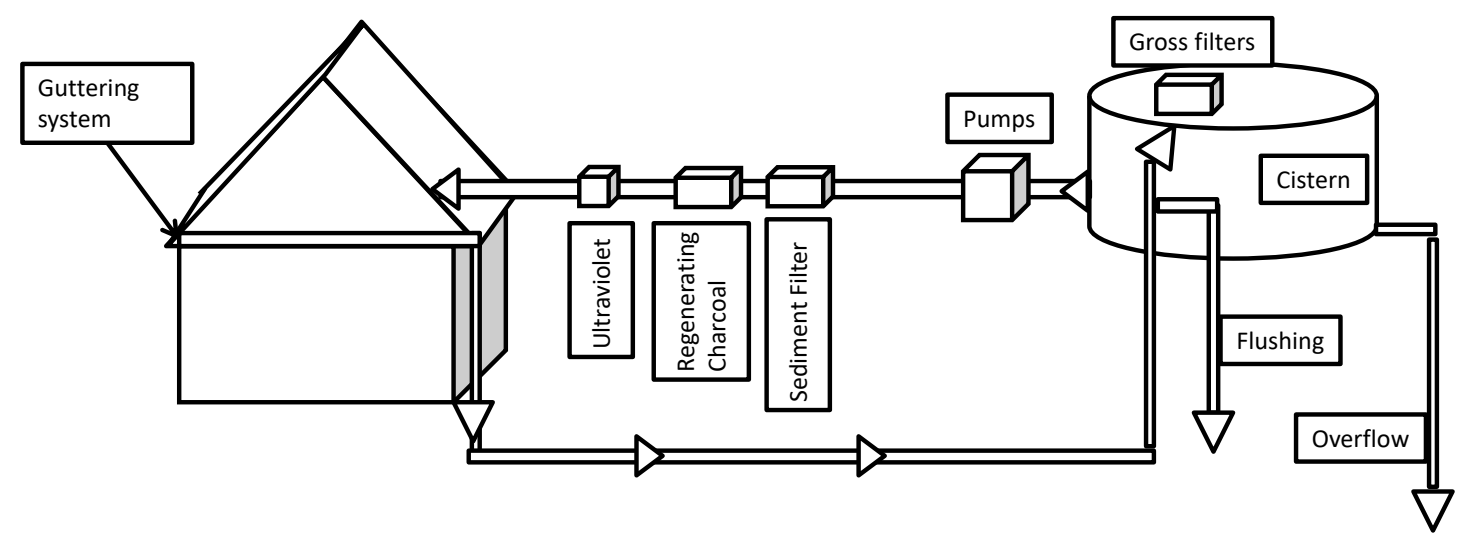

Figure 5. Rainwater harvesting system as designed.

Design of an RWH capable of meeting the needs of an entire household required simulation modeling, so that the distribution of the minimum in the cistern (order statistic) would be strictly greater than zero over all supply and demand considerations and all simulation runs. Details of the simulation are available from $[43,45]$. The final system selected included 4000 square feet of capture space and a 40,000-gallon cistern.

\subsubsection{Environmental Considerations}

Rainwater harvesting was selected for both sustainability and quality considerations; however, RWH is not always the least expensive option even given life-cycle costs [9]. From a sustainability perspective, RWH requires far less water for the same aquifer demand. Specifically, runoff, absorption/adsorption, and evaporation/transpiration reduce aquifer resupply by at least $30 \%$ [87]. On the other hand, RWH systems capture $75 \%$ to $90 \%$ of rainwater, depending on design and rainfall [86]. The amount of water pulled from the aquifer to supply one gallon is therefore at least 3.333 gallons, whereas well RWH systems capturing only $75 \%$ of the available rainfall require 1.333 gallons. The net savings to the aquifer is 2 gallons of water per 1 gallon demanded. Further, the water quality exceeds local and state requirements at the residence and should at similarly constructed residences when the RWH is constructed properly due to minimization of non-point source pollutants. The life-cycle impact for RWH has shown to be better than municipal water as well [88]. RWH also reduces carbon emissions, as water-related energy uses are significant (e.g., 19\% of electricity use in California during the year 2001, [89]).

\subsubsection{Acquisition, Operations, and Maintenance (O\&M) Costs}

Acquisition costs for the rainwater harvesting system (guttering, PVC piping, Pioneer 40K gallon cistern with butyl rubber liner and accessories) cost approximately $\$ 25,500$ in 2020 [90]. Current well drilling prices in Texas are about $\$ 30$ to $\$ 55$ per foot [91]. On this property, a $600^{\prime}$ drilling depth is required. At the average $\$ 42.50$ per foot, the drilling cost alone would run $\$ 25,500$ in 2020 .

Cost to maintain an RWH is reasonable. Ultraviolet tubes (replaced annually for typical use) as well as sediment filters and other system requirements cost approximately $\$ 328$ per year [92]. According to the Centers for Disease Control and Prevention, wells should also be inspected annually [93] at a cost of $\$ 300$ to $\$ 500$ [94]. The 15-year total costs are then $\$ 31,500$ (well) versus $\$ 30,420$ (RWH). When inflated by $3 \%$, the costs are $\$ 33,563$ (well) and $\$ 32,111$ (RWH).

\subsubsection{Qualitative Assessment}

RWH is one of the best features both environmentally and practically. The water purification process results in high-quality, soft water, which is better for water-based appliances like coffee pots and 
dishwashers. There is additional work required that the consumer must understand (filter replacement, gutter cleaning, etc.).

\subsection{Water Fixtures}

Selection of appliances and fixtures is important for a sustainable house reliant on $100 \%$ rainwater. Toilets, shower heads, and other water fixtures were low flow/high pressure, as the rural residence was only plumbed for rainwater harvesting.

\subsubsection{Envrionmental Considerations}

Mayer et al. [95] estimate that toilets use $29 \%$ of indoor water consumption, while water used for showering/bathing, dishwashing, and laundry consume about $36 \%, 14 \%$, and $21 \%$, respectively. The Environmental Protection Agency (EPA) shows that high-pressure, low-flow shower heads reduce flow from 2.5 gallons per minute to 2.0 gallons per minute, a $20 \%$ reduction [96]. In semiarid regions (such as the location for the case study), the use of low-flow fixtures is vital.

\subsubsection{Acquisition and 15-Year O\&M Costs}

Costs for low-flow fixtures are comparable to standard fixtures, depending on brand. Further, Texas law requires the use of low-flow fixtures in new construction [97], so there are no cost acquisition differences measured among possible construction options. While dual-flush toilets are not required by Texas law, they were installed for additional water savings and at no additional cost. Break-even analysis did not include an analysis of low-flow fixtures, as they are required by law and are approximately equivalent in cost.

\subsubsection{Qualitative Assessment}

Most of the low-flow appliances work as well or better than traditional fixtures. Selection of dual-flush toilets, however, must be done after consumer research. Dual-flush should not mean "flush twice." These fixtures have underperformed due to improper selection.

\subsection{Aerobic Septic}

\subsubsection{Environmental Considerations}

Cradle-to-grave water management requires that black water be treated responsibly and sustainably. In this area, aerobic septic systems are required by regulation. The residence construction included a Jet Biologically Accelerated Treatment (BAT) plant (also termed Biologically Accelerated Wastewater Treatment, BAWT, plant). BAT plants work by treating wastewater physically and biologically in a pre-treatment compartment. Water then flows through the treatment compartment where it is aerated, mixed, and treated by a host of biological organisms (a biomass). The mixture then flows to a settlement compartment where particulate matter settles, returning to the treatment compartment, leaving only odorless and clear liquid (gray water produced by the biomass), which is discharged through sprinkler heads [98]. Figure 4 shows the encased BAT system installed at the rural residence. Aerobic systems break down waste far quicker than anaerobic, due to the nature of the bacteria. The benefits to the environment include that: (1) pumps for transporting water to wastewater treatment plants are not necessary (and the associated energy costs); (2) treated water returned to the environment is cleaner; and (3) electricity for processing water (in this case) is largely, if not entirely, generated by the sun.

\subsubsection{Acquisition and O\&M Costs}

There is a cost penalty for installing such a system at this rural residence. Installing an anerobic system averages $\$ 3500$, whereas an aerobic system costs about $\$ 10,500$ [99]. Maintaining the aerobic septic system is about $\$ 200$ annually [100], which is somewhat more than anaerobic systems [101]. 
To account for this differential, anaerobic costs were estimated at $\$ 180$ per year (a $10 \%$ discount). The 15-year acquisition and O\&M costs for aerobic versus anaerobic systems was then estimated (after 3\% inflation for O\&M costs) at $\$ 7531$ (anaerobic) and $\$ 14,128$ (aerobic).

\subsection{Tankless Water Heaters}

One of the current additions to this research residence has been the inclusion of an on-demand electric water heater for a guest room, guest kitchen, and guest bathroom. Tankless electric water heaters require less space than tanked versions and do not constantly use energy to keep water warm. Natural gas options were not available for the case study, and electric heaters powered by PVS were as effective as solar water heaters aside from gray energy considerations.

\subsubsection{Environmental Considerations}

Because any installation would be powered via PVS in the case study residence, there would be only the potential gray energy costs. If operated off of a coal-based grid, tankless electric water heaters would reduce greenhouse gas (GHG) emissions over a tanked system (although a heat pump water heater is even more effective in reducing emissions) [102]. The carbon footprint of tankless electric water heaters is much lower than that of systems with tanks, as it is in operation only when demanded. Tankless water heaters may be $99 \%$ efficient [103].

\subsubsection{Acquisition and 15-Year O\&M Costs}

The acquisition cost of an electric tankless heater is largely dependent on size, capability, and brand and may be larger than traditional tank versions; however, the acquisition cost for the installed unit was identical to the tank unit in this case study. Tankless units may also last 1.5 to 2 times as long as tank water heaters (20 years) and save $8 \%$ to $34 \%$ on water, depending on water demand; however, demand flow for multiple simultaneous operations must be evaluated prior to selection of a device [104].

Comparing the life cycle of a 50-gallon electric water heater with that of a tankless one requires some up-front assumptions. One study indicated that the life-cycle savings over traditional electric storage systems is $\$ 3719$ Australian dollars (about $\$ 2500$ US dollars) [105]. However, that study does not consider the possibility that all electrical power needed is generated by solar power.

The acquisition and installation costs for $2 \times 50$-gallon tank water heaters during initial construction was nearly $\$ 3000$ in the case study residence. Under coal-based grid power, the yearly costs are $\$ 494$ per tank or just under $\$ 1000$ for both systems; however, the case study residence relies on solar and thus avoids these costs. For tankless electric water heaters powered by PVS, the installation and acquisition costs are $\$ 3000$ for two units (high end) with zero annual costs and zero carbon emissions (other than solar gray power as discussed in the limitations).

The initial tanked systems installed were electric Marathon heaters with a lifetime warranty [106]. While there are likely labor costs associated with this warranty, we assume that they are nominal. Thus, operating and maintenance costs for standard water heaters are estimated at $\$ 494$ per tank per year for traditional construction with grid power, while the operation costs for tankless water heaters recharged solely by PVS are $\$ 0$. With identical acquisition costs and (assuming) zero maintenance costs due to warranties, the 15-year total costs are estimated at $\$ 22,914$ (traditional construction with standard tanked water heaters) versus $\$ 3000$ (tankless with 100\% PVS). An assumption is that both systems will not require replacement during the 15-year horizon.

\subsection{Solar Arrays}

In a sustainable home located in semiarid regions, solar arrays are an obvious solution for producing energy requirements. This rural residence initially had installed a $7.25 \mathrm{kWh}$ system (32 $\times 225$ watt panels) with a Sunny Boy inverter ( $\$ 33,600$ in 2011) and then subsequently added 
another $9.585 \mathrm{kWh}$ system $(27 \times 355$ watt panels, $\$ 31,317$ in 2018) with a Solar Edge inverter after home expansion and capitalization of the original solar power system.

\subsubsection{Environmental Considerations}

From installation date until 31 January 2020, the initial $7.25 \mathrm{kWh}$ system has produced 90.579 MWh of power in 35,212 hours of operation for $2.57 \mathrm{kWh}$ per hour, saving 153,984 pounds of $\mathrm{CO}_{2}$ emissions. The $9.585 \mathrm{kWh}$ system has produced $25.86 \mathrm{MWh}$ in about 18,240 hours since installation, saving $40,038.49$ pounds of $\mathrm{CO}_{2}$ emissions and resulting in only $1.4 \mathrm{kWh}$ per hour. (The low result is due to installation in January and a month wait to replace the initial inverter (faulty) in January to February 2018).

The carbon dioxide avoidance by leveraging solar is significant over time. The footprint of solar is $6 \mathrm{~g} \mathrm{CO}_{2} \mathrm{e} / \mathrm{kWh}$, while coal CCS is $109 \mathrm{~g}$ and bioenergy is $98 \mathrm{~g}$. Wind power produces less emissions (4 g each); however, the rural residence location is a low-production wind area [32]. For $3500 \mathrm{kWh}$ per month (or $42 \mathrm{MWh}$ per year), the total annual difference in carbon emissions is 4.326 million $\mathrm{g} / \mathrm{CO}_{2} \mathrm{e}$.

\subsubsection{Acquisition and 15-Year O\&M Costs}

The initial cost of both systems was approximately $\$ 64.917$. After $30 \%$ federal tax credits, the total cost was approximately $\$ 44,441.90$. Initial break-even analysis is based on both acquisition cost and energy cost as if both systems were installed on the expanded house. During the six months of April through September, the residence produced or banked more power than consumed. From October through March, the residence consumed more power than produced. During this month, the residents consumed $1699 \mathrm{kWh}$ and produced only $1226 \mathrm{kWh}$. There is, however, no delivery or cost of power charge, because during the previous months, the residents produced more than consumed. The total consumption estimate is then about $2925 \mathrm{kWh}$ for a 4800 square foot house in a cool month. When averaged over a single year, total consumption is approximately $3500 \mathrm{kWh}$ per month. This equates to between about 1167 and $1750 \mathrm{kWh}$ per person or $0.73 \mathrm{kWh}$ per square foot.

A non-solar house consuming $3500 \mathrm{kWh}$ per month under traditional utility billing at $\$ 0.07$ per $\mathrm{kWh}$ (cost at locality) with a $\$ 14.77$ customer charge (utility company determined) results in an annual estimated cost of $\$ 3117.24$ ( $\$ 259.77 \times 12)$. The same consumption with $100 \%$ solar runs at $\$ 33$ grid-tied fee $\times 12$ months $=\$ 396$. Total costs over 15 years with $3 \%$ inflation per annum are then $\$ 62,834$ (grid electricity) versus $\$ 54,480$ (PVS).

\subsubsection{Qualitative Assessment}

The PVS arrays are one of the best investments of the residence. There have been no uncovered maintenance costs; the systems are reliable. Coupled with the RWH system, the residence benefits from nearly all weather, gathering water from preciptiation and harvesting the sun during even partially overcast days.

\subsection{Electric Car Charging}

\subsubsection{Environmental Considerations}

Electricity generated from PVS was used to charge an electric Nissan Leaf in the case study house. Additional panels were acquired directly for this purpose during the construction. Research suggests that battery electric vehicles (BEVs) may have higher GHG emissions than internal combustion engine vehicles (ICEV) if powered by a grid (at least in China) [107]. Given this research, the only sure way that carbon savings are achieved is charging them through renewable sources.

\subsubsection{Acquisition Costs, 15-Year O\&M Costs, and Residual}

Assuming equivalent acquisition costs for a BEV and ICEV ( $\$ 30,000$ after tax credits), $\$ 2400$ annual gasoline and maintenance costs for the ICEV, $\$ 1200$ annual maintenance for the BEV, identical 
replacement costs at year $7.5(\sim 36,000$ after tax credits), and residual values of $22 \%$ versus $7 \%$ for ICEV and BEV, respectively, results in total costs of $\$ 107,770$ (ICEV) and $\$ 92,288$ (BEV). (ICEVs retain about $45 \%$ of their value over 4 years, while BEVs retain barely more than $25 \%$ on average [6], so using geometric decay over 7.5 years results in about $22 \%$ and $7 \%$ residual value). This estimate includes $3 \%$ inflation for maintenance and gasoline.

\subsubsection{Qualitative Assessment}

Unfortunately, early Nissan Leaf vehicles suffered from battery issues [108]. The owner divested after 3 years partially due to these issues. Improvements in the batteries of these vehicles as well as extended range models makes this vehicle an attractive option for minimizing gasoline and maintenance costs.

\subsection{Geothermal Heating and Cooling}

\subsubsection{Environmental Considerations}

As part of the construction, the rural residence was equipped with a closed-loop, geothermal system (see Figure 4). Vertical, closed-loop geothermal units are heat exchangers that leverage the fact that the temperature 200' below the Earth remains relatively constant. Geothermal systems may save between $25 \%$ and $75 \%$ on energy demands [109].

\subsubsection{Acquisition and O\&M Costs}

The cost of the system including wells, unit, and ducting (complete) was $\$ 26,500$. The tax credit was $30 \%$ or $\$ 7950$, and so the end cost to the resident was $\$ 18,550$. ClimateMaster (the brand installed) estimates a $\$ 1000$ savings in electrical costs per year over an electric heat pump ( $\$ 3135$ versus \$4169) [32]; however, PVS-powered systems have no directly attributable costs except for gray power. The system was replaced with a 5-ton, 18-seer American Standard Platinum heat pump unit in 2018 at a cost of $\$ 16,255$, over $\$ 10,000$ less expensive. (The reason for this replacement is discussed shortly). Assuming equal maintenance costs of $\$ 600$ per year, $3 \%$ inflation of O\&M costs, the 15 -year total cost for geothermal powered by PVS is $\$ 30,644$, whereas the cost for a heat pump and associated O\&M is $\$ 112,383$ (grid-power).

\subsubsection{Qualitative Assessment}

The system operated with limited success for seven years, as the heat exchange and unit were unable to keep up with greater than $100^{\circ} \mathrm{F}\left(38^{\circ} \mathrm{C}\right)$ temperatures in its South Texas location, despite multiple attempts to improve the system (including adding an additional 200' well for heat exchange). This system was the most disappointing, as evidence even post-installation suggested that such a system would be effective in all climates [110]. That was not the experience in this single case study.

\subsection{Generator or Other Backup System}

The residents sought an eco-friendly solar power storage solution (e.g., Tesla Powerwall or the Chinese BYD B-box 10). All options were expensive (between $\$ 80$ to $\$ 110$ per $\mathrm{kWh}$ storage per year for 10 years) with decay rates that generate lithium ion battery disposal concerns after 10 years for most products [111]. Since the storage technology is still developing, a 22-kW propane-powered back-up generator, a device sufficient to empower the entire house (Figure 4), was installed. In well or rainwater harvesting systems that leverage pumps, back-up power is necessary to retain water during electrical outages. Propane is a green fuel that, when burned, has nominal effects on the environment [112]. The 1000-gallon propane tank and generator are sufficient to maintain full power to house for about 14 days under reasonable utilization conditions. The cost for this generator, automatic transfer switch, propane tank, underground installation, and connections was $\$ 19,668.00$. (A large portion of expense 
involved burying the propane tank in rocky terrain.) While included in the discussion, this item is not part of break-even or NPV analysis.

\subsection{Break-Even and NPV Analysis}

Sustainable construction can generate a breakeven for the pocketbook and for the environment. Figure 6 illustrates the cost comparisons of the sustainable construction techniques discussed in this paper. Costs are inflated 3\% per annum and reflect the previously detailed acquisition and O\&M costs. The first matrix in this figure is traditional construction without environmentally intelligent land use. The second reflects the rural residence as designed, and the third matrix reflects sustainable construction without geothermal for the particular locality and residence.

Looking at Figure 6, the break-even year for 2020 construction would be by 2026 . The additional cost of sustainable construction is estimated at $\$ 54,329$, which is much lower than might be expected due to the tax credits associated with solar and geothermal. A 15-year NPV analysis is provided at 3\% and $5 \%$ cost of capital. At $3 \%$, the analysis suggests a 15 -year NPV of $\$ 334,355$ (traditional) versus $\$ 250,339$ million (sustainable), for a difference of $\$ 84 \mathrm{~K}$. At $5 \%$ cost of capital, that difference falls to $\$ 63 \mathrm{~K}$ due to opportunity costs of committing capital up front.

\subsection{Ongoing Sustainable Improvements}

All add-on construction to the rural residence included mini-split HVAC systems (both in-wall and in-roof systems). These systems have more upfront costs but are much more energy efficient, as they do not lose energy through ductwork. Further, they are now inconspicuous and highly effective [113]. Also, these systems allow for better compartmentalization of conditioned air, as they do not rely on a set number of zones. See Figure 4 for pictures of in-roof and in-wall systems installed in the residence. In new construction, these systems should be considered due to their efficiency and elimination of ductwork and other requirements.

Another new construction consideration is the use of wireless multigang light switches. These fixtures can minimize wiring requirements by using a single drop instead of multiple drops. With the advent of 5G, it might be possible to eliminate CAT6 wiring during residential construction in the future as well. 


\begin{tabular}{|c|c|c|c|c|c|c|c|c|c|c|c|c|c|c|c|c|c|}
\hline \multirow{3}{*}{\begin{tabular}{|l|} 
Traditional \\
Framing: Stud
\end{tabular}} & \multirow{2}{*}{$\begin{array}{l}\text { BLS Inflation } \\
\text { Acquisition }\end{array}$} & \multirow{2}{*}{\begin{tabular}{c|}
0.03 \\
O\&M 2020
\end{tabular}} & \multirow{2}{*}{$\frac{0.03}{0 \text { O\&M } 2021}$} & 0.03 & 0.03 & 0.03 & 0.03 & 0.03 & 0.03 & 0.03 & 0.03 & 0.03 & 0.03 & 0.03 & 0.03 & 0.03 & 0.03 \\
\hline & & & & O\&M 2022 & O\&M 2023 & O\&M 2024 & O\&M 2025 & O\&M 2026 & O\&M 2027 & O\&M 2028 & O\&M 2029 & O\&M 2030 & O\&M 2031 & O\&M 2032 & O\&M 2033 & O\&M 2034 & O\&M 2035 \\
\hline & $(52,800)$ & $\$$ & $\$$ & $\$$ & $\$$ & $\$$ & $\$$ & $\$$ & $\$$ & $\$$ & $\$$ & $\$$ & $\$$ & $\$$ & $\$$ & $\$$ & $\$$ \\
\hline Insulation: Fiberglass & $(14,420)$ & $\$$ & $\$$ & $\$$ & $\$$ & $\$$ & $\$$ & $\$$ & $\$$ & $\$$ & $\$$ & $\$$ & $\$$ & $\$$ & $\$$ & - & - \\
\hline Windows/Doors: Standard & $(14,457)$ & $\$$ & $\$$ & $\$$ & $\$$ & $\$$ & $\$$ & $\$$ & $\$$ & $\$$ & $\$$ & $\$$ & $\$$ & $\$$ & - & - & - \\
\hline Water: Well & $\$ \quad(25,500)$ & (400) & (412) & (424) & (437) & (450) & (464) & (478) & (492) & (507) & (522) & (538) & (554) & (570) & (587) & (605) & (623) \\
\hline Wastewater: Anaerobic & $(3,500)$ & (200) & (206) & (212) & (219) & (225) & (232) & (239) & (246) & (253) & (261) & (269) & (277) & (285) & (294) & (303) & (312) \\
\hline Water Heaters: $2 \times$ Tanks & $(3,000)$ & (988) & $\$(1,018)$ & $(1,048)$ & $\$ \quad(1,080)$ & $\$ \quad(1,112)$ & $\$ \quad(1,145)$ & $\$ \quad(1,180)$ & $\$ \quad(1,215)$ & $\$ \quad(1,252)$ & $\$(1,289)$ & $\$ \quad(1,328)$ & $\$ \quad(1,368)$ & $\$(1,409)$ & $\$ \quad(1,451)$ & $\$ \quad(1,494)$ & $\$ \quad(1,539)$ \\
\hline Electricity: Grid & $\$$ & $\$ \quad(3,117)$ & $\$ \quad(3,211)$ & $(3,307)$ & $\$ \quad(3,406)$ & $\$ \quad(3,508)$ & $\$ \quad(3,614)$ & $\$ \quad(3,722)$ & $\$ \quad(3,834)$ & $\$ \quad(3,949)$ & $\$(4,067)$ & $\$(4,189)$ & \$ $(4,315)$ & \$ $(4,444)$ & $\$(4,578)$ & $\$(4,715)$ & $\$ \quad(4,857)$ \\
\hline Vehicle: Gas & $\$ \quad(30,000)$ & $\$ \quad(2,400)$ & $\$ \quad(2,472)$ & $(2,546)$ & $\$ \quad(2,623)$ & $\$ \quad(2,701)$ & $\$ \quad(2,782)$ & $\$ \quad(2,866)$ & \$ $(2,952)$ & $\$(32,440)$ & $\$(3,131)$ & $\$(3,225)$ & $\$(3,322)$ & $\$(3,422)$ & $\$(3,524)$ & $\$(3,630)$ & $\$ \quad(3,739)$ \\
\hline HVAC: Heat Pump & $\$ \quad(16,255)$ & $\$ \quad(4,769)$ & $\$ \quad(4,912)$ & $(5,059)$ & $\$ \quad(5,211)$ & $\$ \quad(5,368)$ & $\$ \quad(5,529)$ & $\$ \quad(5,694)$ & $\$ \quad(5,865)$ & $\$ \quad(6,041)$ & $\$ \quad(6,222)$ & $\$ \quad(6,409)$ & $\$ \quad(6,601)$ & $\$(6,799)$ & $\$ \quad(7,003)$ & $\$ \quad(7,214)$ & $\$ \quad(7,430)$ \\
\hline Net Cash Flows & $\$ \quad(159,932)$ & $\$(11,874)$ & $\$(12,230)$ & $\$ \quad(12,597)$ & $\$(12,975)$ & $\$(13,365)$ & $\$(13,765)$ & $\$(14,178)$ & $\$(14,604)$ & $\$(15,042)$ & $\$(15,493)$ & $\$(15,958)$ & $\$(16,437)$ & $\$(16,930)$ & $\$(17,438)$ & $\$(17,961)$ & $\$(18,500)$ \\
\hline Cumulative Cash Flow & $\$ \quad(159,932)$ & $\$(171,806)$ & $\$(184,036)$ & $\$(196,634)$ & $\$(209,609)$ & $\$(222,974)$ & $\$(236,739)$ & $\$(250,918)$ & $\$(265,521)$ & $\$(280,563)$ & $\$(296,056)$ & $\$(312,014)$ & $\$(328,451)$ & $\$(345,381)$ & $\$(362,819)$ & $\$(380,780)$ & $\$(399,279)$ \\
\hline Net Present Value, $3 \%$ Cost & $\$ \quad(334,355)$ & & & & & & & & & & & & & & & & \\
\hline Net Present Value, $5 \%$ Cost & \$ $\quad(302,081)$ & & & & & & & & & & & & & & & & \\
\hline$\underline{\text { Sustainable }}$ & Acquisition & O\&M 2020 & O\&M 2021 & O\&M 2022 & O\&M 2023 & O\&M 2024 & O\&M 2025 & O\&M 2026 & O\&M 2027 & O\&M 2028 & O\&M 2029 & O\&M 2030 & O\&M 2031 & O\&M 2032 & O\&M 2033 & O\&M 2034 & O\&M 2035 \\
\hline Framing: Engineered & $\$ \quad(53,184)$ & $\$$ & $\$$ & $\$$ & $\$$ & $\$$ & $\$$ & $\$$ & $\$$ & $\$$ & $\$$ & $\$$ & $\$$ & $\$$ & $\$$ & $\$$ & $\$$ \\
\hline Insulation: Icynene & $\$ \quad(12,460)$ & $\$$ & $\$$ & $\$$ & - & - & - & $\$$ & $\$$ & $\$$ & $\$$ & $\$$ & $\$$ & $\$$ & - & - & - \\
\hline Windows/Doors: Energy Star & $\$ \quad(16,625)$ & $\$$ & $\$$ & $\$$ & $\$$ & $\$$ & $\$$ & $\$$ & $\$$ & $\$$ & $\$$ & $\$$ & $\$$ & $\$$ & $\$$ & $\$$ & $\$$ \\
\hline Water: RWH & $\$ \quad(25,500)$ & (328) & (338) & (348) & (358) & $(369)$ & (380) & (392) & (403) & (416) & (428) & (441) & (454) & (468) & (482) & (496) & (511) \\
\hline Wastewater: Aerobic & $\$ \quad(10,500)$ & (180) & (185) & (191) & (197) & (203) & (209) & (215) & (221) & (228) & (235) & (242) & (249) & (257) & (264) & (272) & $(280)$ \\
\hline Water Heaters: $2 \times$ Tankless & $(3,000)$ & & $\$$ & $\$$ & $\$$ & $\$$ & $\$$ & $\$$ & $\$$ & $\$$ & $\$$ & $\$$ & $\$$ & $\$$ & $\$$ & - & - \\
\hline Electricity: PVS & $\$ \quad(44,442)$ & (498) & (513) & (528) & (544) & (561) & (577) & (595) & (612) & (631) & (650) & (669) & (689) & (710) & $(731$ & (753) & (776) \\
\hline Vehicle: Electric & $\$ \quad(30,000)$ & $\$ \quad(1,200)$ & $\$ \quad(1,236)$ & $(1,273)$ & $\$ \quad(1,311)$ & $(1,351)$ & $\$ \quad(1,391)$ & $\$ \quad(1,433)$ & $\$ \quad(1,476)$ & $\$(39,620)$ & $\$ \quad(1,566)$ & $\$ \quad(1,613)$ & $\$ \quad(1,661)$ & $\$ \quad(1,711)$ & $\$(1,762)$ & $\$ \quad(1,815)$ & $\$ \quad(1,870)$ \\
\hline HVAC: Geothermal & $\$ \quad(18,550)$ & (600) & (618) & (637) & (656) & (675) & (696) & (716) & (738) & (760) & (783) & (806) & (831) & (855) & (881) & (908) & (935) \\
\hline Net Cash Flows & $\$ \quad(214,261)$ & $\$(2,806)$ & $\$(2,890)$ & $(2,977)$ & $\$ \quad(3,066)$ & $\$ \quad(3,158)$ & $\$ \quad(3,253)$ & $\$ \quad(3,351)$ & $\$ \quad(3,451)$ & $\$ \quad(3,555)$ & $\$ \quad(3,661)$ & $\$ \quad(3,771)$ & $\$ \quad(3,884)$ & $\$ \quad(4,001)$ & $\$ \quad(4,121$ & $\$ \quad(4,244)$ & $\$ \quad(4,372)$ \\
\hline Cumulative Cash Flow & $\$ \quad(214,261)$ & $\$(217,067)$ & $\$(219,957)$ & $\$(222,934)$ & $\$(226,000)$ & $\$(229,158)$ & $\$(232,411)$ & $\$(235,762)$ & $\$(239,213)$ & $\$(242,767)$ & $\$(246,429)$ & $\$(250,200)$ & $\$(254,084)$ & $\$(258,084)$ & $\$(262,205)$ & $\$(266,449)$ & $\$(270,821)$ \\
\hline Net Present Value, $3 \%$ Cos & $\$ \quad(250,339)$ & & & & & & & & & & & & & & & & \\
\hline Net Present Value, 5\% Cost & $\$ \quad(239,449)$ & & & & & & & & & & & & & & & & \\
\hline
\end{tabular}

Figure 6. Color-coded break-even and NPV analysis. 


\section{Discussion}

\subsection{Break-Even and NPV Analyses}

For this case study, the break-even analysis and ROI suggest that sustainable land use and construction efforts can benefit the environment and the bottom line, which is congruent with other research [114]. The initial up-front costs may be quickly offset by savings depending on construction options, but there are upfront costs that must be considered as found in previous research [115]. In the case study here, only seven years were required for breakeven, which is earlier than empirical simulation might have suggested [9], possibly due to synergistic effects of multiple interventions applied simultaneously. This timeframe might be reduced by selecting subsets of options such as energy efficient HVAC versus geothermal HVAC, as in the hybrid ROI option investigated. Aside from the economic considerations, the environmental responsibility issues are clear. Avoiding carbon emissions is responsible construction.

In the break-even analysis, there were several construction options that resulted in near-zero break-even time, including the use of engineered lumber, Icynene foam, and Energy Star doors and windows. Other options such as $100 \%$ PVS and the purchase of an electric car saw delayed break-even points. Some sustainable efforts never saw any breakeven, including the aerobic septic system. Geothermal proved ineffective and expensive based on residents' desires and requirements, which runs counter to other evidence suggesting its utility in office buildings in another semiarid climate (Madrid), which does not have quite the same temperature spread as the location in Texas [116].

The additional cost of sustainable construction for the research residence in this case is estimated at $\$ 54,329$, and the 15 -year NPV analysis showed $\$ 84 \mathrm{~K}$ and $\$ 63 \mathrm{~K}$ savings at $3 \%$ and $5 \%$ cost of capital for sustainable construction, respectively. There may be a positive return on investment for intelligent land use, transportation, and construction. Tax incentives and education are still necessary to encourage smart decisions and incentivize individuals [117]. These findings help inform construction decisions for businesses and for individuals in this region.

\subsection{Environmental Findings}

Perhaps more importantly, there is a significant environmental offset for this type of construction. Based on reasonable assumptions, the construction of this house saved between 25 and 90 trees due to the use of reclaimed wood [9]. The carbon dioxide avoidance by leveraging solar is significant, although there is a break-even consideration based on economic and environmental trade-offs congruent with other research [118]. The total estimated annual difference in carbon emissions was 4.326 million $\mathrm{g} / \mathrm{CO}_{2} \mathrm{e}$ for this research residence. Environmental effects of burning gasoline in a vehicle were reduced to near zero by powering a BEV via PVS, and associated savings were achieved as in other research [6].

Further, the total water offset per demanded gallon is 2 gallons of water per 1 gallon demanded. A traditional residence consuming 10,000 gallons would require 33,333 gallons of rainfall to supply the ground water sources, whereas a rainwater system would require only 13,333 gallons. In semiarid regions, that difference is important for sustainability and aquifer preservation [43,45]. This rural residence illustrates that smart land use and sustainable construction save resources.

Aside from the sustainable options discussed in this case study, there are many, many more that might be considered, particularly with engineered performance improvement of materials. One example of this is the use of spent coffee grounds to improve thermal insulation [119]. Another example is the use of a prototype hybrid steel and wood purlins for roof construction rather than pure steel [120]. Materials improvements are likely to reduce environmental impacts of residential construction.

\subsection{Policy Implications}

There are also policy requirements for sustainable construction. That policy push towards sustainable construction is evolving to a universal mandate with penalties for failure to comply. The prime example is in California, where a new law passed a solar mandate where all new homes 
built after 1 January 2020 must be equipped with a solar electric system. That system must be sized that it will offset $100 \%$ of the home's electricity usage. This mandate is one aspect of the California Energy Commission's initiative to have $50 \%$ of the entire State of California's energy production be from a clean energy source by 2030 [121]. Continuing with the California mandates on sustainability mandates, California passed another law recently signed by Gov. Brown that imposes water usage requirements. The law states that all California residents will be restricted to 55 gallons/day water usage by 2022 and is reduced to 50 gallons/day by 2030 [122]. While both initiatives discuss the mandates, neither has shown the penalty for failure to comply or even specifics on implementation. What is clear is that the mandates on both electric and water usage are the wave of the future and appear to be only the start in California, with certainty that other states will adopt similar measures. A proactive approach leveraging the analysis presented here and elsewhere will help both builders and buyers.

\subsection{Limitations}

This is a single case study of a single rural residence, where some efforts were successful (e.g., solar power arrays and rainwater harvesting) and some were not (e.g., geothermal). The results for this single case study in a semiarid region are not generalizable to other regions. Further, land-use regulations vary from location to location, so what is achievable at this research location may be prohibited elsewhere. The case study is also limited in that complete cradle-to-grave life-cycle costs and impacts are not available for all components and that, as a case study, only one alternative technology was priced and investigated. For every category of construction, there are many available sustainable products. Where possible, we have documented environmental considerations; however, these are not the universe of effects.

Another major limitation of this study is that it does not include complete transaction costs (see [123-125]. Where possible, these are documented; however, they are nontrivial to estimate. Any final analysis should seek to improve these cost estimates.

\section{Conclusions}

\subsection{Key Findings}

This case study illustrates that proper rural residential construction and resource use can provide value to the consumer and reduce the impact of the built environment. There is a positive NPV obtainable for many eco-friendly construction options. A reasonable break-even expectation for sustainable construction options based on these construction requirements in this geographical area would be six years without geothermal HVAC, and the cost for the breakeven is $\$ 54,329$. The NPV suggested that the sustainable option was still the better choice at $3 \%$ and $5 \%$ cost of capital. Leveraging what works for both the environment and the consumer in a particular region requires dedication and focus of the residential construction industry.

Most important are the environmental offsets. By using sustainable building practices for new houses and renovations which are required in rural areas of Texas [56], carbon offsets and water conservation may be achieved, reducing the impact of the built environment on our planet. The savings for this single research property alone is estimated at 4.326 million $\mathrm{g} / \mathrm{CO}_{2} \mathrm{e}$ annually. The effect of such sustainable building construction in rural communities may slow climate change.

\subsection{Future Research}

As a research residence, the design elements are not static. One element of future research includes adding lithium ion battery (LIB) backups for the PVS to achieve total grid separation. Understanding the feasibility, life-cycle costs, and environmental break-even of this effort would inform future engineering considerations, as evidence suggests LIB production has some carbon tail [126]. As part of future research, the team plans on evaluating the reduction of CAT6 Ethernet cables by adopting a true 
wireless solution and the reduction of electrical wire by using dual-gang wireless light switches and requiring only one wired component.

Aside from the residence interventions, future research will include a metanalysis of rural residential construction literature. Discovering best practices from multiple reports is important for generalizability beyond this case study. Sustainable construction options should positively affect the environment and the pocketbook.

Author Contributions: Conceptualization, L.F.; methodology, L.F., B.B.; validation, S.K., K.L.; formal analysis, L.F., B.B.; writing, L.F., B.B., M.B., K.L, S.K. All authors have read and agreed to the published version of the manuscript.

Funding: This research received no external funding.

Conflicts of Interest: The authors declare no conflict of interest.

\section{References}

1. Araújo, A.G.; Pereira Carneiro, A.M.; Palha, R.P. Sustainable construction management: A systematic review of the literature with meta-analysis. J. Clean. Prod. 2020, 256, 120350. [CrossRef]

2. Belayutham, S.; González, V.A.; Yiu, T.W. A cleaner production-pollution prevention based framework for construction site induced water pollution. J. Clean. Prod. 2016, 135, 1363-1378. [CrossRef]

3. Heravi, G.; Abdolvand, M.M. Assessment of water11virtual water. consumption during production of material and construction phases of residential building projects. Sustain. Cities Soc. 2019, 51, 101785. [CrossRef]

4. Rahman, M.M.; Rahman, M.A.; Haque, M.M.; Rahman, A. Sustainable Water Use in Construction. In Sustainable Construction Technologies; Tam, V.W.Y., Le, K.N., Eds.; Butterworth-Heinemann: Oxford, UK, 2019; Chapter 8; pp. 211-235.

5. Fulton, L. Ownership Cost Comparison of Battery Electric and Non-Plugin Hybrid Vehicles: A Consumer Perspective. Appl. Sci. 2018, 8, 1487. [CrossRef]

6. Fulton, L. Publicly available simulation of battery electric, hybrid electric, and gasoline vehicles. Energies 2020. In Press.

7. Fulton, L.; Bastian, N. A Fuel Cost Comparison of Electric and Gas-Powered Vehicles. In Proceedings of the 2012 AutumnSim Conference on Energy, Climate and Environmental Modeling \& Simulation, San Diego, CA, USA, 28-31 October 2012.

8. Reyna, J.L.; Chester, M.V. Energy efficiency to reduce residential electricity and natural gas use under climate change. Nat. Commun. 2017, 8, 14916. [CrossRef]

9. Fulton, L.; Bradley, B.; Matthew, B.; Clemens Scott, K.; Lee, K. A Publicly Available Cost Simulation of Sustainable Construction Options for Residential Houses. Sustainability 2020, 12, 2873. [CrossRef]

10. Buehlmann, U.; Bumgardner, M.; Alderman, D. Recent Developments in US Hardwood Lumber Markets and Linkages to Housing Construction. Curr. For. Rep. 2017, 3, 213-222. [CrossRef]

11. Li, F.; Liu, X.; Zhang, X.; Zhao, D.; Liu, H.; Zhou, C.; Wang, R. Urban ecological infrastructure: An integrated network for ecosystem services and sustainable urban systems. J. Clean. Prod. 2017, 163, S12-S18. [CrossRef]

12. Fearnside, P.M.; Lashof, D.A.; Moura-Costa, P. Accounting for time in Mitigating Global Warming through land-use change and forestry. Mitig. Adapt. Strateg. Glob. Chang. 2000, 5, 239-270. [CrossRef]

13. Hossain, M.U.; Poon, C.S. Global warming potential and energy consumption of temporary works in building construction: A case study in Hong Kong. Build. Environ. 2018, 142, 171-179. [CrossRef]

14. Patz, J.; Norris, D. Land Use Change and Human Health. In Ecosystems and Land Use Change; AGU: Washington, DC, USA, 2004; pp. 159-167. [CrossRef]

15. Rodríguez-Gallego, L.; Achkar, M.; Defeo, O.; Vidal, L.; Meerhoff, E.; Conde, D. Effects of land use changes on eutrophication indicators in five coastal lagoons of the Southwestern Atlantic Ocean. Estuar. Coast. Shelf Sci. 2017, 188, 116-126. [CrossRef]

16. Křeček, J.; Palán, L.; Stuchlík, E. Impacts of land use policy on the recovery of mountain catchments from acidification. Land Use Policy 2019, 80, 439-448. [CrossRef]

17. Yong, L.; Hans Peter, H.A.; Xiaodong, S.; Yu, S. Research on the relationship between urban form and urban smog in China. Environ. Plan. B Plan. Des. 2016, 44. [CrossRef] 
18. Kardinal Jusuf, S.; Wong, N.H.; Hagen, E.; Anggoro, R.; Hong, Y. The influence of land use on the urban heat island in Singapore. Habitat Int. 2007, 31, 232-242. [CrossRef]

19. Suh, S.; Tomar, S.; Leighton, M.; Kneifel, J. Environmental Performance of Green Building Code and Certification Systems. Environ. Sci. Technol. 2014, 48, 2551-2560. [CrossRef]

20. Wald, M. Why More Solar Panels Should Be Facing West, Not South. New York Times, 1 December 2014.

21. Gromicko, N. Building Orientation for Optimum Energy. Available online: https://www.nachi.org/buildingorientation-optimum-energy.htm (accessed on 21 April 2020).

22. Ahn, C.; Pan, W.; Lee, S.; Peña-Mora, F.A. Lessons learned from utilizing discrete-event simulation modeling for quantifying construction emissions in pre-planning phase. In Proceedings of the 2010 Winter Simulation Conference, Baltimore, MD, USA, 5-8 December 2010; pp. 3170-3176.

23. Erol, H.; Dikmen, I.; Birgonul, M.T. Measuring the impact of lean construction practices on project duration and variability: A simulation-based study on residential buildings. J. Civ. Eng. Manag. 2017, 23, 241-251. [CrossRef]

24. Bossink, B.A.G.; Brouwers, H.J.H. Construction Waste: Quantification and Source Evaluation. J. Constr. Eng. Manag. 1996, 122, 55-60. [CrossRef]

25. Johnston, H.; Mincks, W.R. Cost-effective waste minimization for construction managers: A Publication of the American Association of Cost Engineers a Publication of the American Association of Cost Engineers. Cost Eng. 1995, 37, 31.

26. Mon, R. Engineered lumber: An alternative to old-growth resources. J. For. 1993, 91, 9-12.

27. Harte, A.M. Mass timber - the emergence of a modern construction material. J. Struct. Integr. Maint. 2017, 2, 121-132. [CrossRef]

28. Ajayi, S. Design, Procurement and Construction Strategies for Minimizing Waste in Construction Projects. Ph.D. Thesis, University of the West of England, Bristol, UK, 2020.

29. Icynene. What You Need to Know About Spray Foam Insulation. Available online: https://www.icynene. com/en-us/blog/what-you-need-know-about-spray-foam-insulation (accessed on 20 April 2020).

30. Sadineni, S.B.; Madala, S.; Boehm, R.F. Passive building energy savings: A review of building envelope components. Renew. Sustain. Energy Rev. 2011, 15, 3617-3631. [CrossRef]

31. Kuczyński, T.; Staszczuk, A. Experimental study of the influence of thermal mass on thermal comfort and cooling energy demand in residential buildings. Energy 2020, 195, 116984. [CrossRef]

32. Pehl, M.; Arvesen, A.; Humpenöder, F.; Popp, A.; Hertwich, E.G.; Luderer, G. Understanding future emissions from low-carbon power systems by integration of life-cycle assessment and integrated energy modelling. Nat. Energy 2017, 2, 939-945. [CrossRef]

33. Hohne, P.A.; Kusakana, K.; Numbi, B.P. A review of water heating technologies: An application to the South African context. Energy Rep. 2019, 5, 1-19. [CrossRef]

34. Coffman, M.; Bernstein, P.; Wee, S. Integrating electric vehicles and residential solar PV. Transp. Policy 2017, 53, 30-38. [CrossRef]

35. Jain, M.; Hoppe, T.; Bressers, H. A Governance Perspective on Net Zero Energy Building Niche Development in India: The Case of New Delhi. Energies 2017, 10, 1144. [CrossRef]

36. Connelly, D. Net Positive Energy Building. ASHRAE J. 2016, 58, 56.

37. Browne, S. The 'Greenest' Home in Texas. Available online: https://www.ksat.com/weather/2012/02/09/thegreenest-home-in-texas/ (accessed on 21 April 2020).

38. Doroudchi, E.; Alanne, K.; Okur, Ö.; Kyyrä, J.; Lehtonen, M. Approaching net zero energy housing through integrated EV. Sustain. Cities Soc. 2018, 38, 534-542. [CrossRef]

39. Wagner, M.W.; Kreuter, U.P. Groundwater Supply in Texas: Private Land Considerations in a Rule-of-Capture State. Soc. Nat. Resour. 2004, 17, 349-357. [CrossRef]

40. Zheng, Y.; Flanagan, S.V. The Case for Universal Screening of Private Well Water Quality in the U.S. and Testing Requirements to Achieve It: Evidence from Arsenic. Environ. Health Perspect. 2017, 125, 085002. [CrossRef] [PubMed]

41. Kross, B.C.; Hallberg, G.R.; Bruner, D.R.; Cherryholmes, K.; Johnson, J.K. The nitrate contamination of private well water in Iowa. Am. J. Public Health 1993, 83, 270-272. [CrossRef] [PubMed]

42. Kross, B.C.; Selim, M.I.; Hallberg, G.R.; Bruner, D.R.; Cherryholmes, K. Pesticide contamination of private well water, a growing rural health concern. Environ. Int. 1992, 18, 231-241. [CrossRef] 
43. Fulton, L.V.; Nathaniel, D.B.; Francis, A.M.; Muzaffer, R. Rainwater harvesting system using a non-parametric stochastic rainfall generator. Simulation 2013, 89, 693-702. [CrossRef]

44. Fulton, L.V. A Simulation of Rainwater Harvesting Design and Demand-Side Controls for Large Hospitals. Sustainability 2018, 10, 1659. [CrossRef]

45. Fulton, L.; Musal, R.; Mendez-Mediavilla, F. Construction analysis of rainwater harvesting systems. In Proceedings of the Winter Simulation Conference, Berlin, Germany, 9-12 December 2012; pp. 1-11.

46. DeOreao, W.B.M.P.; Dziegielewski, B.; Kiefe, J. Residential End Uses of Water, Version 2. Available online: https://www.circleofblue.org/wp-content/uploads/2016/04/WRF_REU2016.pdf (accessed on 21 April 2020).

47. Asgarzadeh, M.; Vahdati, K.; Lotfi, M.; Arab, M.; Babaei, A.; Naderi, F.; Pir Soufi, M.; Rouhani, G. Plant selection method for urban landscapes of semi-arid cities (a case study of Tehran). Urban For. Urban Green. 2014, 13, 450-458. [CrossRef]

48. Show, K.Y.; Lee, D.J. 8-Anaerobic Treatment Versus Aerobic Treatment. In Current Developments in Biotechnology and Bioengineering; Lee, D.-J., Jegatheesan, V., Ngo, H.H., Hallenbeck, P.C., Pandey, A., Eds.; Elsevier: Amsterdam, The Netherlands, 2017; pp. 205-230.

49. Sustainability \& Green Building. Available online: https:/www.nahb.org/Advocacy/Industry-Issues/ Sustainability-and-Green-Building (accessed on 21 April 2020).

50. NAHB Model Green Home Buiding Checklist. Available online: https://americanolean.com/pdfs/leed/ NAHBChecklist.pdf (accessed on 21 April 2020).

51. Renewables on the Rise 2019. Available online: https://environmenttexas.org/reports/txe/renewables-rise2019 (accessed on 23 April 2020).

52. Wind Energy in Texas. Available online: https://www.awea.org/Awea/media/Resources/StateFactSheets/ Texas.pdf (accessed on 21 April 2020).

53. Census Bureau. County Population by Characteristics: 2010-2018; Census Bureau: Washington, DC, USA, 2020.

54. R Development Core Team. R: A Language and Environment for Statistical Computing; R Core Team: Vienna, Austria, 2018.

55. Lamstein, A. choroplethr: Simplify the Creation of Choropleth Maps in R. Available online: https:/CRAN.Rproject.org/package=choroplethr (accessed on 21 April 2020).

56. Bowen National Research, L.L.C. Texas Statewide Rural Housing Analysis; Texas Department of Housing and Community Affairs: Austin, TX, USA.

57. Malewitz, J. High Power Rates Spark Outrage in Rural Texas. Available online: https://www.texastribune. org/2016/01/23/sky-high-rates-spark-power-outrage-rural-texas/ (accessed on 23 April 2020).

58. Schmidt, M. Find Break Even Point, Volume, in 5 Steps from Costs and Revenues. Available online: https://www.business-case-analysis.com/break-even-analysis.html (accessed on 21 April 2020).

59. Baker, S. Perils of the Internal Rate of Return. Available online: http://sambaker.com/econ/invest/invest.html (accessed on 21 April 2020).

60. Goel, A.; Ganesh, L.S.; Kaur, A. Sustainability assessment of construction practices in India using inductive content analysis of research literature. Int. J. Constr. Manag. 2019, 1-14. [CrossRef]

61. CCEO | Required Permits. Available online: https://cceo.org/mainpage/buildingreqs (accessed on 23 April 2020).

62. New Braunfels Utilities Electrical Connection Policy. Available online: http://www.nbutexas.com/ Commercial/New-Commercial-Construction/Electrical-Connection-Policy (accessed on 23 April 2020).

63. Google. Google Maps Imagery@2020 CAPCOG Maxar Technologies. Available online: https://www. currentresults.com/Weather/US/average-annual-state-sunshine.php (accessed on 23 April 2020).

64. De Magalhães, R.F.; Danilevicz, Â.d.M.F.; Saurin, T.A. Reducing construction waste: A study of urban infrastructure projects. Waste Manag. 2017, 67, 265-277. [CrossRef]

65. Morel, J.C.; Mesbah, A.; Oggero, M.; Walker, P. Building houses with local materials: Means to drastically reduce the environmental impact of construction. Build. Environ. 2001, 36, 1119-1126. [CrossRef]

66. Begum, R.A.; Siwar, C.; Pereira, J.J.; Jaafar, A.H. A benefit-cost analysis on the economic feasibility of construction waste minimisation: The case of Malaysia. Resour. Conserv. Recycl. 2006, 48, 86-98. [CrossRef]

67. Ortiz, O.; Pasqualino, J.C.; Castells, F. Environmental performance of construction waste: Comparing three scenarios from a case study in Catalonia, Spain. Waste Manag. 2010, 30, 646-654. [CrossRef] [PubMed]

68. Friedman, A. Constructing a Home. In Fundamentals of Sustainable Dwellings; Island Press/Center for Resource Economics: Washington, DC, USA, 2012; pp. 65-81. 
69. De Silva, S.; Liyanage, V. Suitability of finger jointed structural timber for construction. J. Struct. Eng. Appl. Mech. 2010, 2, 131-142. [CrossRef]

70. Bradshaw, S. McMansions Are not Eco-Friendly. Available online: https://www.seattletimes.com/business/ real-estate/mcmansions-are-not-eco-friendly/ (accessed on 21 April 2020).

71. $2 \times 4 \times 104-5 / 8^{\prime \prime}$ Pre-Cut Stud Construction/Framing Lumber. Available online: https://www.menards.com/main/ building-materials/lumber-boards/dimensional-lumber/2-x-4-pre-cut-stud-construction-framing-lumber/ 1021305/p-1444422686698.htm (accessed on 14 April 2020).

72. $2 \times 4 \times 1045 / 8^{\prime \prime}$ Finger Joint Pre-Cut Stud Construction/Framing Lumber. Available online: https://www.menards.com/main/building-materials/lumber-boards/dimensional-lumber/2-x-4-fingerjoint-pre-cut-stud-construction-framing-lumber/1021111/p-1444422419687.htm (accessed on 1 April 2020).

73. Learn How Much It Costs to Install Carpentry Framing. Available online: https://www.homeadvisor.com/ cost/walls-and-ceilings/install-carpentry-framing/ (accessed on 1 April 2020).

74. Li, Y.; Yu, H.; Sharmin, T.; Awad, H.; Gül, M. Towards energy-Efficient homes: Evaluating the hygrothermal performance of different wall assemblies through long-term field monitoring. Energy Build. 2016, 121, 43-56. [CrossRef]

75. Kunič, R. Carbon footprint of thermal insulation materials in building envelopes. Energy Effic. 2017, 10, 1511-1528. [CrossRef]

76. Learn About the Cost of Projects in the Insulation Category. Available online: https://www.homeadvisor. com/cost/insulation/ (accessed on 1 April 2020).

77. Kalhor, K.; Ememinejad, N. Qualitative and quantitative optimization of thermal insulation materials: Insights from the market and energy codes. J. Build. Eng. 2020, 30, 101275. [CrossRef]

78. How Much Does Spray Foam Insulation Cost? Available online: https://www.icynene.com/en-us/blog/howmuch-does-spray-foam-insulation-cost-1 (accessed on 2 May 2020).

79. Foam Insulation vs. Fiberglass, Cellulose: Which Is the Right Choice? Available online: https://www. probuilder.com/insulation-choices-fiberglass-cellulose-or-foam (accessed on 1 April 2020).

80. What Makes It ENERGY STAR? Available online: https://www.energystar.gov/products/building_products/ residential_windows_doors_and_skylights/key_product_criteria (accessed on 1 April 2020).

81. Benefits of ENERGY STAR Qualified Windows, Doors, and Skylights. Available online: https://www. energystar.gov/products/building_products/residential_windows_doors_and_skylights/benefits (accessed on 4 May 2020).

82. Rodriguez, J. Home Builders: What You Need to Know about Low-E Windows? Available online: https: //www.thebalancesmb.com/uses-of-low-e-windows-844755 (accessed on 1 April 2020).

83. Bruegge, C.; Carrión-Flores, C.; Pope, J.C. Does the housing market value energy efficient homes? Evidence from the energy star program. Reg. Sci. Urban Econ. 2016, 57, 63-76. [CrossRef]

84. Modernize. Energy Efficient Window Costs-2020 Prices Guide-Modernize. Available online: https: //modernize.com/windows/energy-efficient (accessed on 21 April 2020).

85. Sisti, M.; Schiavano, G.F.; Santi, M.D.; Brandi, G. Ultraviolet germicidal irradiation in tap water contaminated by Aspergillus spp. J. Prev. Med. Hyg. 2017, 58, E315-E319. [CrossRef]

86. Krishna, H.J.; Brown, C.; Gerston, J.; Colley, S. The Texas Manual on Rainwater Harvesting, 3rd ed.; Texas Water Development Board: Austin, TX, USA, 2005.

87. Rain and Precipitation. Available online: https://www.usgs.gov/special-topic/water-science-school/science/ rain-and-precipitation?qt-science_center_objects=0\#qt-science_center_objects (accessed on 21 April 2020).

88. Ghimire, S.R.; Johnston, J.M.; Ingwersen, W.W.; Sojka, S. Life cycle assessment of a commercial rainwater harvesting system compared with a municipal water supply system. J. Clean. Prod. 2017, 151, 74-86. [CrossRef]

89. Klein, G. California's Water-Energy Relationship; California Energy Commission: Sacramento, CA, USA, 2005.

90. Above Ground Rainwater Collection Tanks by Rain Ranchers. Available online: https://rainranchers.com/ above-ground-rainwater-collection-tanks/ (accessed on 1 April 2020).

91. Learn How Much It Costs to Drill a Well. Available online: https://www.homeadvisor.com/cost/landscape/ drill-a-well/ (accessed on 1 April 2020).

92. Solloway, C. Rainwater Harvesting; EPA-841-R-13-002; U.S. Environmental Protection Agency (EPA): Washington, DC, USA, 2013.

93. Well Maintenance | Wells | Private Water Systems | Drinking Water | Healthy Water | CDC. Available online: https://www.cdc.gov/healthywater/drinking/private/wells/maintenance.html (accessed on 1 April 2020). 
94. 2020 Average Well Inspection Cost (with Price Factors). Available online: https://www.thumbtack.com/p/ well-inspection-cost (accessed on 1 April 2020).

95. WaterResearch. Residential, Commercial, and Institutional End Uses of Water. Available online: https: //www.waterrf.org/research/projects/residential-commercial-and-institutional-end-uses-water (accessed on 1 April 2020).

96. US Environmental Protection Agency. Showerheads. Available online: https://www.epa.gov/watersense/ showerheads (accessed on 1 April 2020).

97. Plumbing Fixtures: Water Saving Standards. Available online: https:/www.tceq.texas.gov/permitting/water_ rights/wr_technical-resources/plumbing-fixtures (accessed on 1 April 2020).

98. Jet Aeration System. Available online: http:/jetprecast.com/jet-aeration-system.html (accessed on 1 April 2020).

99. 2020 Septic Tank System Installation Costs \& Replacement Prices. Available online: https://homeguide.com/ costs/septic-tank-system-cost (accessed on 1 April 2020).

100. Cost of an Aerobic vs. Anaerobic Septic System (2020)-How Much Does Septic Tank Installation Cost? Price Comparison. Available online: https://www.kompareit.com/homeandgarden/plumbing-compare-aerobicvs-anaerobic-septic-system.html (accessed on 1 April 2020).

101. Basics for Septic Systems. Available online: https://www.tceq.texas.gov/assistance/water/fyiossfs.html (accessed on 1 April 2020).

102. Hong, B.; Howarth, R.W. Greenhouse gas emissions from domestic hot water: Heat pumps compared to most commonly used systems. Energy Sci. Eng. 2016, 4, 123-133. [CrossRef]

103. Sustainability Society. Available online: http://www.eemax.com/2016/01/11/3-environmental-and-economicbenefits-of-tankless-water-heaters/ (accessed on 1 April 2020).

104. Tankless or Demand-Type Water Heaters. Available online: https://www.energy.gov/energysaver/heat-andcool/water-heating/tankless-or-demand-type-water-heaters (accessed on 1 April 2020).

105. Kumar, N.M.; Mathew, M. Comparative life-cycle cost and GHG emission analysis of five different water heating systems for residential buildings in Australia. Beni Suef Univ. J. Basic Appl. Sci. 2018, 7, 748-751. [CrossRef]

106. Marathon Water Heaters-Consumers Power Inc. Available online: https://www.cpi.coop/home-energy-use/ water-heaters/marathon-water-heaters/ (accessed on 2 April 2020).

107. Li, Y.L.; Ningning, H.; Tingting. Research on Carbon Emissions of Electric Vehicles throughout the Life Cycle Assessment Taking into Vehicle Weight and Grid Mix Composition. Energies 2019, 12, 3612. [CrossRef]

108. Vinkhuyzen, M. Nissan's Long Strange Trip with LEAF Batteries. Available online: https://cleantechnica. com/2018/09/29/nissans-long-strange-trip-with-leaf-batteries/ (accessed on 1 April 2020).

109. Pinto, A.; Rodrigues, F.; Mota, A. Geothermal contribution on southern Europe climate for energy efficiency of university buildings. Winter season. Energy Procedia 2017, 134, 181-191. [CrossRef]

110. Choudhury, A. HVAC vs. Geothermal Heat Pump. Open J. Energy Effic. 2013, 2, 42-45. [CrossRef]

111. Complete Solar Battery Review-Clean Energy Reviews. Available online: https://www.cleanenergyreviews. info/blog/2015/11/19/complete-battery-storage-comparison-and-review (accessed on 1 April 2020).

112. The Homeowners' Guide to Propane vs. Natural Gas: A Comparison of Differences, Cost, Efficiency and Safety | Petro Home Service. Available online: https://www.petro.com/resource-center/propane-vs-naturalgas-cost-efficiency-safety (accessed on 1 April 2020).

113. Appliance, C. Mini-Split Heat Pumps: The Advantages \& Disadvantages. Available online: https://learn. compactappliance.com/mini-split-heat-pumps/ (accessed on 1 April 2020).

114. Hu, M. Does zero energy building cost more?-An empirical comparison of the construction costs for zero energy education building in United States. Sustain. Cities Soc. 2019, 45, 324-334. [CrossRef]

115. Ade, R.; Rehm, M. Reaching for the stars: Green construction cost premiums for Homestar certification. Constr. Manag. Econ. 2020, 38, 570-580. [CrossRef]

116. Alañón, J.I.V.; Alberto, V.; Arteaga, I.d.; Roberto, Q.; Alejandro. A Comparative Energy and Economic Analysis between a Low Enthalpy Geothermal Design and Gas, Diesel and Biomass Technologies for a HVAC System Installed in an Office Building. Energies 2019, 12, 870. [CrossRef]

117. Martek, I.; Hosseini, M.R.; Shrestha, A.; Edwards, D.J.; Durdyev, S. Barriers inhibiting the transition to sustainability within the Australian construction industry: An investigation of technical and social interactions. J. Clean. Prod. 2019, 211, 281-292. [CrossRef] 
118. Ren, M.; Mitchell, C.R.; Mo, W. Dynamic life cycle economic and environmental assessment of residential solar photovoltaic systems. Sci. Total Environ. 2020, 722, 137932. [CrossRef]

119. Lachheb, A.; Allouhi, A.; El Marhoune, M.; Saadani, R.; Kousksou, T.; Jamil, A.; Rahmoune, M.; Oussouaddi, O. Thermal insulation improvement in construction materials by adding spent coffee grounds: An experimental and simulation study. J. Clean. Prod. 2019, 209, 1411-1419. [CrossRef]

120. Osa, H.G.; Mikel, Z.; Jesús, C.; Juan, L. Sustainability Improvement in the Design of Lightweight Roofs: A New Prototype of Hybrid Steel and Wood Purlins. Sustainability 2018, 11, 39. [CrossRef]

121. Bach, N. California Becomes 1st State to Require Solar Panels on New Homes. Available online: https: //fortune.com/2018/12/06/california-solar-panels-new-homes/ (accessed on 1 April 2020).

122. Luna, T.; Koseff, A. Get ready to save water: Permanent California restrictions approved by Gov. Jerry Brown. Available online: https://www.sacbee.com/news/politics-government/capitol-alert/article211333594.html (accessed on 1 April 2020).

123. Buitelaar, E. A Transaction-cost Analysis of the Land Development Process. Urban Stud. 2004, 41, $2539-2553$. [CrossRef]

124. Shahab, S.; Clinch, J.P.; O’Neill, E. Accounting for transaction costs in planning policy evaluation. Land Use Policy 2018, 70, 263-272. [CrossRef]

125. McCann, L. Transaction costs and environmental policy design. Ecol. Econ. 2013, 88, 253-262. [CrossRef]

126. Tang, Y.W.; Yajuan, Y.; Kai, H.; Baojun. From the Perspective of Battery Production: Energy-Environment-Economy (3E) Analysis of Lithium-Ion Batteries in China. Sustainability 2019, 11, 6941. [CrossRef]

(C) 2020 by the authors. Licensee MDPI, Basel, Switzerland. This article is an open access article distributed under the terms and conditions of the Creative Commons Attribution (CC BY) license (http://creativecommons.org/licenses/by/4.0/). 